\title{
FUNDAMENTOS E CONTROLE DA PROGRESSIVIDADE NO IMPOSTO SOBRE A RENDA
}

\author{
Dissertação de Mestrado \\ Orientador: Professor Titular Dr. Luís Eduardo Schoueri
}

UNIVERSIDADE DE SÃO PAULO

FACULDADE DE DIREITO

São Paulo - SP 

RAPHAEL ASSEF LAVEZ

\title{
FUNDAMENTOS E CONTROLE DA PROGRESSIVIDADE NO IMPOSTO SOBRE A RENDA
}

\begin{abstract}
Dissertação apresentada à Banca Examinadora do Programa de Pós-Graduação em Direito da Faculdade de Direito da Universidade de São Paulo, como exigência parcial para obtenção do título de Mestre em Direito na área de concentração Direito Econômico, Financeiro e Tributário, sob a orientação do Prof. Titular Dr. LUís EDUARDO SCHOUERI.
\end{abstract}

UNIVERSIDADE DE SÃO PAULO

FACULDADE DE DIREITO

São Paulo - SP 
Autorizo a reprodução e divulgação parcial deste trabalho, por qualquer meio convencional ou eletrônico, para fins de estudo e pesquisa, desde que citada a fonte.

\section{Catalogação da Publicação \\ Serviço de Biblioteca e Documentação \\ Faculdade de Direito da Universidade de São Paulo}

Lavez, Raphael Assef

Fundamentos e Controle da Progressividade no Imposto sobre a Renda / Raphael Assef Lavez; orientador Luís Eduardo Schoueri -- São Paulo, 2017.

$260 \mathrm{p}$.

Dissertação (Mestrado - Programa de Pós-Graduação em Direito - Direito Econômico, Financeiro e Tributário) - Faculdade de Direito, Universidade de São Paulo, 2017.

1. Progressividade. 2. Imposto sobre a renda. 3. Capacidade contributiva.

4. Desigualdade. 5. Direitos fundamentais. I. Schoueri, Luís Eduardo, orient. II. Título. 
Nome: LAVEZ, Raphael Assef.

Título: Fundamentos e Controle da Progressividade no Imposto sobre a Renda

Dissertação apresentada à Faculdade de Direito da Universidade de São Paulo como exigência parcial para obtenção do título de Mestre em Direito.

Aprovado em:

BANCA EXAMINADORA

Prof.

Assinatura:

Prof.

Assinatura:

Prof.

Assinatura:
Instituição:

Julgamento:

Instituição:

Julgamento:

Instituição:

Julgamento: 

A Abdo Esmael Assef (in memoriam), que sempre nos ensinou para onde deveríamos olhar; e a Felipe Assef Gonsales, um dos que mais bem aprendeu sua lição. 

Pesquisar, portanto, os efeitos progressivos ou regressivos do imposto para decidir sobre sua constitucionalidade ou não [...] não é mais, após a Constituição de 1988, pugnar por princípios meramente éticos, morais ou econômicos ao sabor de uma determinada ideologia. É fazer a correta interpretação do sistema tributário, estritamente jurídica e necessária a uma razoável aplicação do comando constitucional.

Misabel Abreu Machado Derzi *

\footnotetext{
* Nota de atualização. In: BALEEIRO, Aliomar. Limitações constitucionais ao poder de tributar. $8^{\mathrm{a}}$ ed. Rio de Janeiro: Forense, 2010, p. 1.377.
} 



\section{RESUMO}

LAVEZ, Raphael Assef. Fundamentos e controle da progressividade no imposto sobre a renda. 2017. 260 f. Dissertação (Mestrado) - Faculdade de Direito, Universidade de São Paulo, São Paulo, 2017.

A presente pesquisa tem por objetivo reexaminar os fundamentos constitucionais da progressividade no imposto sobre a renda para, assim, avaliar os mecanismos de controle derivados da própria norma constitucional, tanto com relação ao dever do legislador em estruturar um imposto sobre a renda progressivo quanto aos limites para sua consecução, à luz dos direitos fundamentais dos contribuintes. Para tanto, deve-se revisitar a relação entre progressividade e capacidade contributiva, isto é, se existe uma relação de justificação entre elas, seja com vistas à teoria do benefício, seja no tocante às teorias do sacrifício ou numa compensação frente à regressividade de determinados tributos sobre o consumo. Afastada a capacidade contributiva como fundamento da progressividade, identifica-se na última uma efetiva restrição ao direito fundamental a contribuir em conformidade com a capacidade contributiva. Enquanto tal, assume centralidade a justificação da progressividade com base em fundamentos diretos (no caso do imposto sobre a renda), mas especialmente indiretos, sejam eles por dedução ou indução, conforme se verifiquem princípios ou regras constitucionais, com maior ou menor grau de generalidade, que podem deduzir ou induzir justificação de um imposto voltado à redução da desigualdade de renda e de sua concentração. Da releitura da Constituição com esse foco, constroem-se tanto uma regra de competência para a instituição de um imposto com um esquema progressivo de alíquotas quanto um princípio relacionado ao objetivo de que aqueles que mais têm contribuam com uma maior proporção de sua renda. Essa proposta é importante, pois faz derivar da Constituição os limites ao legislador ordinário tanto com relação à configuração de elementos que mitiguem esse objetivo (deduções, exclusões, isenções e tributação cedular), e o consequente dever de justificação crescente à medida dessa mitigação, quanto ao controle a que se submete a progressividade face às restrições que inflige aos direitos fundamentais dos contribuintes.

Palavras-chave: Progressividade. Imposto sobre a renda. Capacidade contributiva. Desigualdade. Direitos fundamentais 



\begin{abstract}
LAVEZ, Raphael Assef. Fundaments and control of the progressive income taxation. 2017. 260 p. Dissertation (Master's Degree) - Faculty of Law, University of São Paulo, São Paulo, 2017.

The purpose of this research is to reexamine the constitutional fundaments of the progressive income taxation and their influence over the judicial control based on the constitutional rules and principles. This control deals both with the obligation of the legislative body to institute a progressive income tax and with the restriction of other constitutional rights granted to taxpayers. For this reason, the relation between progressivity and ability to pay should be analyzed, as well as whether the latter grounds the former. This exam should reevaluate the theories of benefit, sacrifice and compensation, reaching the conclusion that the ability to pay principle does not ground a progressive taxation. Conversely, such graduated rate scheme restrains the constitutional right to pay taxes in accordance to the ability to pay criterion. In this context, the justification of progressive taxation of income becomes crucial under its constitutional fundaments. They may be either direct or indirect, all of them related to the objective of income inequality reduction. From this point of view, it is possible to build a rule that determines the progressivity of income tax, as well as a principle which establishes the objective that the richest individuals shall contribute to the government with a proportionally higher share of their income. That would be a measure to undermine the deep income inequality in Brazil. This proposal is relevant to set limits not only to the legislative activity when it is establishing exceptions, exclusions or deductions to the income tax base (which mitigate such objective), but also to the violation of the constitutional rights of the taxpayers.
\end{abstract}

Keywords: Progressivity. Income tax. Ability to pay. Inequality. Constitutional rights. 



\section{SUMÁRIO}

INTRODUÇÃO. 1

1. Por que a progressividade no imposto sobre a renda? 1

2. Sob quais perspectivas analisar a progressividade no imposto sobre a renda? ..............5

3. Quais aspectos da progressividade no imposto sobre a renda? .................................. 9

1. CAPACIDADE CONTRIBUTIVA E PROGRESSIVIDADE NO IMPOSTO SOBRE A RENDA ............................................................................................................... 11

1.1. Considerações iniciais: discriminação, igualdade e a ideia de fundamento ............. 11

1.2. A capacidade contributiva na justificação dos impostos ....................................... 13

1.3. Progressividade no imposto sobre a renda e sua justificação ................................. 22

1.3.1. Primeiras ideias: teoria do benefício como fundamento do imposto progressivo

1.3.2. Progressividade no imposto sobre a renda e capacidade contributiva.......

1.3.2.1. Progressividade como corolário e exigência da capacidade contributiva .... 31

1.3.2.2. Progressividade como concretização da capacidade contributiva globalmente

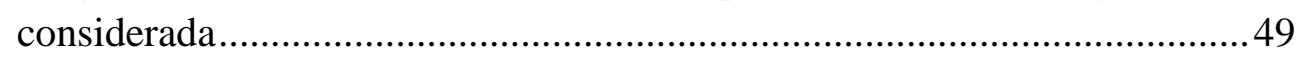

1.3.2.3.Progressividade como restrição ao direito fundamental a contribuir em conformidade com a capacidade contributiva...........................................53

\section{A PROGRESSIVIDADE NO IMPOSTO SOBRE A RENDA NA CONSTITUIÇÃO} FEDERAL

2.1. Considerações iniciais: fundamentos da progressividade para além da capacidade contributiva

2.2. Progressividade, redução das desigualdades sociais e (re)distribuição de renda..... 62

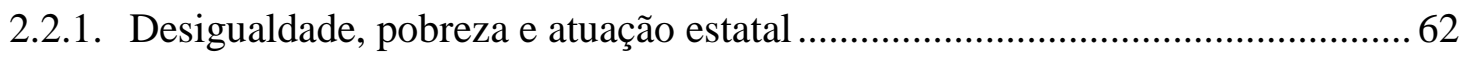

2.2.2. Progressividade, (re)distribuição de renda e a "crítica do gasto público" ........ 69

2.3. Fundamentos da progressividade no imposto sobre a renda na Constituição

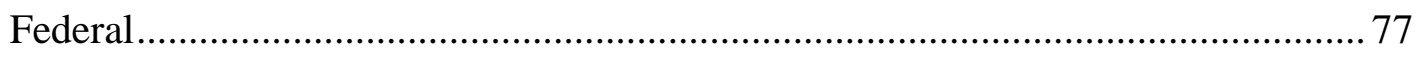

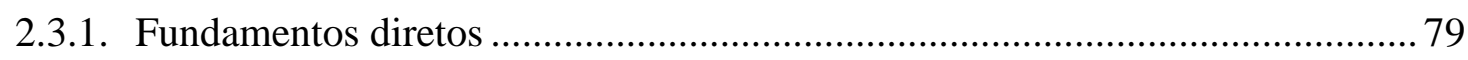




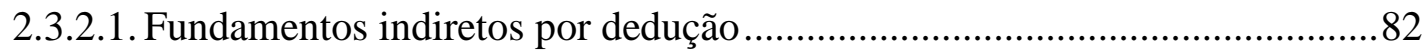

2.3.2.1.1. Estado Social e Democrático de Direito ..............................................8 82

2.3.2.1.2. Construção de uma sociedade livre, justa e solidária ..........................87

2.3.2.1.3. Erradicação da pobreza e da marginalização e redução das

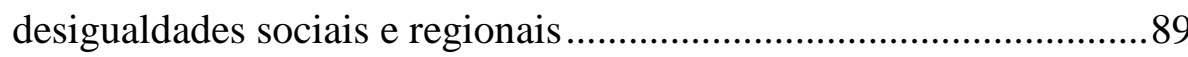

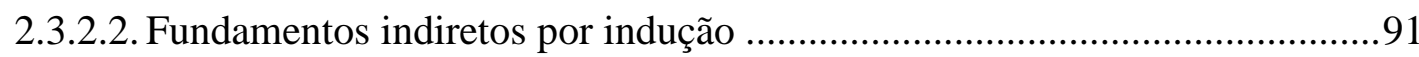

2.3.2.2.1. Sistema de seguridade social: saúde, previdência social e assistência

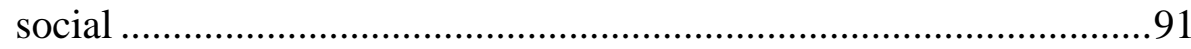

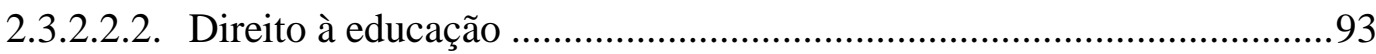

2.3.2.2.3. Direito à alimentação, ao trabalho, à moradia, ao lazer, à segurança, à proteção à maternidade e à infância .................................................99

2.4. Construção da norma constitucional da progressividade .......................................95

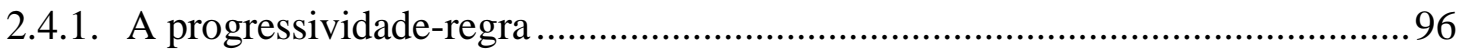

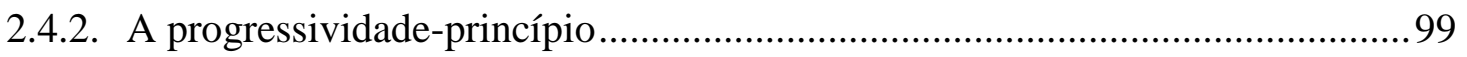

2.4.3. A inviabilidade de uma progressividade-postulado em razão dos postulados da legalidade e da igualdade 104

\section{PROGRESSIVIDADE, BASE DE CÁlCULO E SISTEMÁTICA DE} TRIBUTAÇÃO DO IMPOSTO SOBRE A RENDA

3.1. Considerações iniciais: o objetivo da progressividade e o dever crescente de

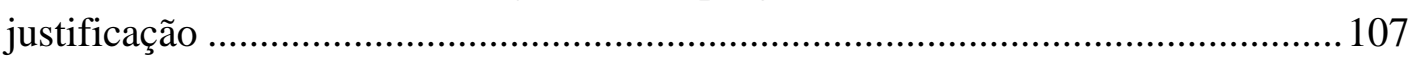

3.2. $\mathrm{O}(\mathrm{s})$ conceito(s) de renda como ponto de partida................................................. 109

3.2.1. Progressividade e a abrangência do conceito de renda ................................... 109

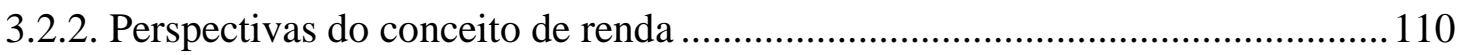

3.2.2.1. Renda a partir do consumo (e satisfação) ................................................111

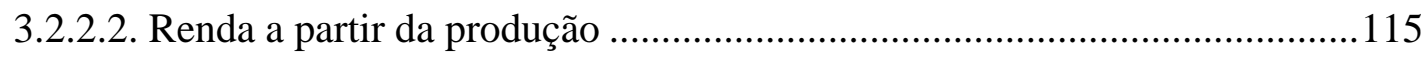

3.2.2.2.1. Teoria da fonte e renda-produto .....................................................115

3.2.2.2.2. Teoria do acréscimo patrimonial e conceito abrangente de renda .......116

3.2.3. Conceito de renda no sistema tributário brasileiro ......................................... 120

3.2.3.1. A questão do conceito constitucional de renda......................................120 
3.2.3.1.1. Tipos e conceitos na delimitação constitucional da competência tributária

3.2.3.1.2. Conceito constitucional pressuposto de renda e o papel da lei complementar em matéria de competência tributária

3.2.3.2. Definição de renda no Código Tributário Nacional: conceito abrangente e restrições

3.3. Base de cálculo do imposto sobre a renda e progressividade

3.3.1. "Isenção" do mínimo existencial como decorrência do conceito de renda e o problema dos efeitos inflacionários na progressividade

3.3.2. Deduções de despesas da base de cálculo do imposto. 136

3.3.3. Efeitos distorcivos de isenções e exclusões da base de cálculo em um esquema progressivo de alíquotas.

3.4. Sistemática de tributação da renda e progressividade

3.4.1. Tributação cedular, restrição à progressividade e necessidade de justificação 150

3.4.2. Tributação (progressiva) dos ganhos de capital 156

3.4.3. Tributação das rendas empresariais e a integração entre pessoas jurídicas e pessoas físicas

\section{CRITÉRIOS PARA O CONTROLE DA PROGRESSIVIDADE NO IMPOSTO} SOBRE A RENDA

4.1. Considerações iniciais: disciplina constitucional da progressividade e seu controle.

4.2. Direitos fundamentais dos contribuintes e progressividade no imposto sobre a renda.

4.3. Exame da proporcionalidade e regra constitucional originária da progressividade no imposto sobre a renda

4.3.1. Aspectos gerais do exame de proporcionalidade da progressividade no imposto sobre a renda 178

4.3.1.1. Subexame de adequação 181

4.3.1.2. Subexame de necessidade 185

4.3.1.3. Subexame de proporcionalidade em sentido estrito 187 
4.3.2. Inviabilidade do exame de proporcionalidade e a regra constitucional da progressividade

4.4. Exame de correspondência entre a regra constitucional e a regra de incidência da progressividade.

4.5. Exame de razoabilidade e o dever de congruência na discriminação 197

4.6. Vedação ao tributo com efeitos de confisco e sua aplicação à progressividade no imposto sobre a renda.

4.6.1. Proibição de excesso, conteúdo essencial dos direitos fundamentais e vedação ao tributo com efeitos de confisco

4.6.2. Progressividade no imposto sobre a renda, efeitos de confisco e livre exercício da atividade econômica

4.6.2.1. Natureza do controle: abstrata ou concreta .209

4.6.2.2. Abrangência do controle: tributo a tributo ou sistema tributário como um todo 211

4.6.2.3. Objeto do controle: alíquotas marginais ou alíquotas efetivas .216

4.7. Outros critérios de controles: complementariedade, subsidiariedade e economicidade

4.8. Uma última palavra sobre o controle da progressividade no imposto sobre a renda 


\section{INTRODUÇÃO}

\section{Por que a progressividade no imposto sobre a renda?}

O problema da progressividade nos impostos ocupou papel central no debate tributário brasileiro por mais de uma década. Diversas questões foram colocadas, tanto pela doutrina quanto pelo Supremo Tribunal Federal: a progressividade conforme a base de cálculo do imposto decorre da capacidade contributiva? É por ela exigida? Pode aplicar-se a todos os impostos ou, ao contrário, é necessária a autorização expressa da Constituição para seu emprego?

Em comum a todas essas questões, há o fato de que raramente disseram respeito ao imposto sobre a renda, especialmente se considerados os debates travados no âmbito do Supremo Tribunal Federal. Deveras, o artigo 153, § $2^{\circ}$, inciso I, da Constituição mencionaa expressamente nessa hipótese, ao prescrever que o imposto "será informado pelos critérios da generalidade, da universalidade e da progressividade, na forma da lei”. Talvez seja pela previsão constitucional direta dessa hipótese que o Min. Ilmar Galvão tenha sido taxativo no sentido de que "a progressividade, no imposto sobre a renda, visa à realização de uma política de distribuição de renda"1.

\footnotetext{
${ }^{1}$ Cf. Supremo Tribunal Federal, Recurso Extraordinário 153.771/MG, Plenário, Rel. p/ acórdão Min. Moreira Alves, j. 20.11.1996, DJ 05.09.1997, p. 55.
} 
Se a Constituição já a prevê, parece resolvida a questão da progressividade no imposto sobre a renda, reservando-a ao debate com relação a outros tributos em que essa disposição não seja tão clara. Todavia, até mesmo se comparada com outras situações em que mencionada, a disciplina da progressividade no imposto sobre a renda é extremamente sucinta, reduzindo-se à sua "proclamação". Significaria isso uma ampla liberdade do legislador ordinário, dada pela Constituição, para a instituição de qualquer progressividade, com relação a qualquer critério ou medida de comparação?

Surge, nesse ponto, um aspecto relevante: a construção do comando ao legislador ordinário, nesse tema, exige a atribuição de um conteúdo à norma constitucional da progressividade o qual, como é evidente, não pode se limitar àquele singelo dispositivo. Isso porque não basta partir de qualquer graduação de alíquotas: diversos esquemas podem ser cogitados, como a graduação de alíquotas do imposto sobre a renda incidentes sobre aplicações no mercado financeiro, variáveis regressivamente conforme o prazo dos investimentos, por exemplo. Seria essa a progressividade a que se refere a Constituição? À primeira vista, não parece que seja a isso que se refira o texto constitucional. É, portanto, necessário ir além.

Avançar na construção da norma constitucional da progressividade significa, naturalmente, determinar os seus fundamentos. A noção de fundamento da norma toca fundo a questão acerca daquilo que justifica a discriminação por ela levada a efeito. Nessa perspectiva, vale revisitar a problemática relação entre progressividade e capacidade contributiva, agora com ênfase no imposto sobre a renda: se um certo contribuinte que aufere renda correspondente ao dobro daquela auferida por outro pagará mais que o dobro do imposto pago pelo outro (em razão da progressividade), cabe questionar: a sua capacidade contributiva também seria superior ao dobro daquela externada pelo segundo? A esse propósito: tratando do imposto sobre a renda, há alguma medida da capacidade contributiva que não a própria renda? Faz sentido afirmar que um dado sujeito que aufira o dobro da renda de outro possua uma capacidade contributiva superior a esse dobro?

Se afastada, por hipótese, a capacidade contributiva enquanto fundamento da progressividade no imposto sobre a renda, remanescerá a questão da sua justificação. Segundo o Min. Ilmar Galvão, ela repousa numa "política de distribuição de renda". A Constituição Federal embasa uma atuação estatal voltada à intervenção da alocação de riqueza realizada pelo livre mercado? Pode servir o imposto como instrumento de uma “política de distribuição de renda"? Afinal, numa primeira análise, a redução da pobreza parece dizer muito mais respeito ao gasto público, ou seja, como são aplicados os recursos 
provenientes do imposto, se são destinados às camadas mais vulneráveis da população - e não ao imposto em si, quanto e de quem é arrecadado. Seja como for, fica a questão: a redução (ou erradicação) da pobreza e a diminuição das desigualdades (especialmente de renda) se confundem enquanto objetivos e quanto aos instrumentos para alcançá-los?

Essas questões compõem o pano de fundo da construção dos fundamentos da progressividade no imposto sobre a renda no contexto da Constituição Federal, indo além, portanto, do seu artigo $153, \S 2^{\circ}$, inciso I, já que ela, por ser um corpo orgânico e sistêmico, implica que tais decisões interpretativas dependam do elenco de certa hierarquia a determinados argumentos em detrimento de outros, num processo argumentativo que, ao fim e ao cabo, deverá referir-se à própria Constituição e ao sistema jurídico como um todo ${ }^{2}$.

Da norma constitucional da progressividade no imposto sobre a renda, por sua vez, decorre a conformação, quanto a esse tributo, do âmbito de competência do legislador ordinário. Isso porque, delineados os fundamentos que indutiva e dedutivamente embasamna e lhe atribuem determinado sentido, haverá inquestionável restrição à discricionariedade do legislador na sua estruturação. De fato, tratando-se do imposto sobre a renda, não será qualquer desenho legislativo que atenderá àquele comando constitucional - e medidas infraconstitucionais que estejam em dissonância com ele deverão, no mínimo, ser justificadas em outros princípios ou valores que, ponderados, sobreponham-se à progressividade enquanto um objetivo colocado pela norma constitucional.

Contudo, independentemente do fundamento com que se justifique a progressividade no imposto sobre a renda, o poder de tributar se sujeita a limites materiais também decorrentes do próprio texto constitucional. Na realidade, se ela inflige a determinados contribuintes uma incidência desproporcionalmente mais gravosa se comparados a outros grupos, haverão de se avaliar direitos fundamentais que venham a ser restringidos por tal medida que, portanto, deve ser objeto de controle ${ }^{3}$.

Esse problema é extremamente pertinente num contexto em que os tributos também passam a desempenhar funções cruciais na vida pública, além do mero financiamento estatal ${ }^{4}$. Isso porque, ainda que se entenda o tributo como forma essencial de garantia de uma pretendida "liberdade coletiva" pelo Poder Público, consistente na

${ }^{2}$ Cf. ÁVILA, Humberto. Função da ciência do direito tributário: do formalismo epistemológico ao estruturalismo argumentativo. In: Revista Direito Tributário Atual, vol. 29, 2013, pp. 181-204 (198-199).

${ }^{3} \mathrm{Cf}$. VELLOSO, Andrei Pitten. O princípio da isonomia tributária: da teoria da igualdade ao controle das desigualdades impositivas. Porto Alegre: Livraria do Advogado, 2010, pp. 323-325; LEÃO, Martha Toribio. A (des)proporcionalidade da progressividade do Imposto de Renda da Pessoa Física no sistema brasileiro. In: Revista Direito Tributário Atual, vol. 28, 2013, pp. 181-205 (197).

${ }^{4}$ Cf. SCHOUERI, Luís Eduardo. Direito tributário. $7^{\mathrm{a}}$ ed. São Paulo: Saraiva, 2017, p. 36. 
necessidade de que se assegurem a todos os cidadãos condições materiais mínimas para o exercício pleno da liberdade em todas as suas facetas, fato é que, tendo em vista o aprofundamento do processo democrático em geral e particularmente no caso brasileiro, o exercício do poder estatal de tributar se sujeita a limites constitucionais.

Tais limites, na medida em que se transforma a própria função dos tributos no desempenho da atividade estatal, não mais se restringem às limitações formais procedimentais (tais como a legalidade ou a anterioridade), mas também se referem a limitações substanciais diretas ${ }^{5}$. Destacam-se, dentre as últimas, tanto aquelas atinentes à capacidade contributiva enquanto limite quantitativo do ônus tributário ${ }^{6}$ (acima do qual o tributo deixa de garantir a liberdade dos cidadãos, tolhendo-a ${ }^{7}$ ) quanto aquelas atreladas à igualdade que se impõe no tratamento dos contribuintes - e, também, às chamadas desigualdades impositivas decorrentes do texto constitucional ${ }^{8}$.

Daí por que acertado afirmar que o tema da pesquisa é, a um só tempo, bifronte: de um lado, busca-se a construção da norma constitucional da progressividade no imposto sobre a renda, a partir de seus fundamentos; de outro, conforme sua justificação, propõe-se um método de controle da própria progressividade, à luz dos direitos fundamentais dos contribuintes. Trata-se, pois, de duas normas jurídicas distintas a serem analisadas. De um lado, a norma constitucional da progressividade, particularmente quanto à sua justificação; de outro, a norma infraconstitucional de incidência progressiva, enquanto objeto do controle de constitucionalidade frente a direitos fundamentais do contribuinte.

Adicionalmente, essa investigação assume especial relevância no contexto brasileiro, em que são estabelecidas, pela Constituição Federal, dentre os objetivos da República, a construção de uma sociedade livre, justa e solidária, a erradicação da pobreza e da marginalização, além da redução das desigualdades sociais e regionais, o que leva à necessidade de avaliar o papel da tributação nesse sentido. Sob essa perspectiva, parece haver pouco espaço para uma atuação pretensamente neutra do legislador, que deve

\footnotetext{
${ }^{5}$ A respeito das espécies de limitações positivas ao poder de tributar e suas categorias, cf. ÁVILA, Humberto. Sistema constitucional tributário. $5^{a}$ ed. São Paulo: Saraiva, 2012, pp. 129-133.

${ }^{6}$ Cf. SCHOUERI, Luís Eduardo. Direito tributário. $7^{a}$ ed. São Paulo: Saraiva, 2017, pp. 40-41.

${ }^{7}$ Cf. KIRCHHOF, Paul. Der sanfte Verlust der Freiheit. München, Wien: Carl Hanser, 2004, p. 49 apud SCHOUERI, Luís Eduardo. Direito tributário, p. 36.

${ }^{8}$ A respeito da dúbia relação entre a padronização e o princípio da igualdade, ora exigindo-a como garantia de cognoscibilidade do direito, ora limitando-a por impor tratamentos desiguais a situações desiguais que não possam ser padronizadas, cf. VELLOSO, Andrei Pitten. O princípio da isonomia tributária: da teoria da igualdade ao controle das desigualdades impositivas. Porto Alegre: Livraria do Advogado, 2010, pp. $266-267$.
} 
reconhecer, no objeto de sua atividade, verdadeiro veículo para a concretização de tais objetivos constitucionalmente consagrados ${ }^{9}$.

Ocorre que, ao contrário, o sistema tributário brasileiro parece, à primeira vista, reforçar uma dimensão jurídica da desigualdade social, isto é, estar desenhado de modo a acentuar a desigualdade ao invés de combatê-la ${ }^{10}$. Isso tudo pelo fato de que determinados arranjos jurídicos implicam uma incidência precipuamente regressiva, seja em razão da elevada carga tributária incidente sobre o consumo, seja pela constatação de que tributos sobre a renda, cuja progressividade se suporia, ficam aquém do seu potencial de diminuição da desigualdade de renda em razão da existência de mecanismos que mitigam ou até neutralizam sua progressividade ${ }^{11}$. É nesse sentido, portanto, a relevância de avaliar as características do imposto sobre a renda, em particular aqueles aspectos que corroboram e especialmente - aqueles que podem mitigar os objetivos correlatos à progressividade.

\section{Sob quais perspectivas analisar a progressividade no imposto sobre a renda?}

Um mesmo tema pode ser enfrentado por meio de diversas racionalidades. No particular tocante à progressividade, poderia ser proposta uma abordagem mais econômica que jurídica, em que se pretendesse perquirir acerca dos impactos da progressividade, a partir de análises quantitativas, na redução das desigualdades ou mesmo na alocação de riquezas na sociedade ${ }^{12}$, o que não é o caso da presente pesquisa.

Entretanto, é bom frisar, o afastamento da abordagem econômica da progressividade não significa, de outra banda, que se ignorarão elementos próprios da economia ou da ciência das finanças ${ }^{13}$. Mesmo porque propor o isolamento da análise jurídica de qualquer influência decorrente de constatações realizadas por outros campos do saber seria valer-se do reducionismo enquanto método epistemológico, o que não se mostra compatível com a complexidade do tema. Além disso, não se pode deixar de levar em consideração que o fenômeno tributário está envolto num ambiente não jurídico, repleto de

\footnotetext{
${ }^{9}$ Cf. SCHOUERI, Luís Eduardo. Normas tributárias indutoras e intervenção econômica. Rio de Janeiro: Forense, 2005, pp. 2-3.

${ }^{10}$ Cf. COUTINHO, Diogo R. Direito, desigualdade e desenvolvimento. São Paulo: Saraiva, 2013, p. 82.

${ }^{11}$ Cf. Ibid., pp. 80-81.

12 Exemplos dessa abordagem podem ser encontrados em HAYEK, Friedrich. Reexaminando a tributação progressiva. Trad. Edson Bini. In: FERRAZ, Roberto (coord.). Princípios e Limites da Tributação. São Paulo: Quartier Latin, 2005, pp. 739-764.

${ }^{13}$ Cf. SCHOUERI, Luís Eduardo. Normas tributárias indutoras e intervenção econômica, pp. 4-5.
} 
condicionantes e determinantes aos quais o direito não é imune. Relevante, pois, que se busquem explicar "as múltiplas razões políticas, éticas e econômicas de ser do direito tributário", não ignorando "os efeitos que o direito tributário provoca na política, na ética, na economia" ${ }^{14}$. Evita-se perder, assim, a percepção do entorno do fenômeno jurídicotributário, bem como a sua dimensão relacional ${ }^{15}$.

Tudo isso para firmar que a análise da eficácia externa das normas, inclusive tributárias, constitui parte fundamental da ciência do direito, sem a qual acabam sendo deixados de lado os bens jurídicos promovidos e, especialmente, restringidos em razão da aplicação das normas tributárias ${ }^{16}$. Os exemplos de aspectos do direito tributário que não podem ser desconsiderados sob a pecha de "não jurídicos" são inúmeros: o ônus econômico da tributação, o exame do mínimo existencial, a eficiência e praticabilidade administrativas, interesses econômicos dos contribuintes, efeitos confiscatórios do tributo, análise dos efeitos da tributação no sentido da promoção de determinadas finalidade públicas e restrição de direitos fundamentais - e tantos outros poderiam ser aventados -, apontando para um alargamento do objeto do direito tributário para que também abranja os efeitos concretos, bens e interesses dos contribuintes que são restringidos pela incidência tributária ${ }^{17}$.

Em síntese, a consideração dos efeitos econômicos de determinada norma tributária, no campo da dogmática jurídica, assume relevância na exata medida em que se constatam inúmeros exemplos de normas positivadas no ordenamento jurídico, cujo real alcance e compreensão dependerão, inexoravelmente, de considerações econômicas ou próprias da ciência das finanças ${ }^{18}$. Trata-se de autênticas normas jurídicas por razão das quais, a partir da verificação de seus efeitos econômicos, surgirão consequências jurídicas próprias (como a sua inconstitucionalidade, quando contrários a princípios informadores da Ordem Constitucional Econômica, por exemplo ${ }^{19}$ ).

\footnotetext{
${ }^{14}$ FOLLONI, André. Ciência do direito tributário no Brasil: crítica e perspectivas a partir de José Souto Maior Borges. São Paulo: Saraiva, 2013, p. 334.

${ }^{15}$ Cf. SCHOUERI, Luís Eduardo. Direito tributário. $7^{\mathrm{a}}$ ed. São Paulo: Saraiva: 2017, p. 23; FOLLONI, André. Ciência do direito tributário no Brasil, pp. 338-341.

${ }^{16}$ Cf. ÁVILA, Humberto. Sistema constitucional tributário. 5a ed. São Paulo: Saraiva, 2012, p. 140.

${ }^{17}$ Cf. ÁVILA, Humberto. Prefácio. In: FOLLONI, André. Ciência do direito tributário no Brasil, pp. 15-22 (19).

18 Podem-se citar, a esse respeito, a efetiva intervenção no domínio econômico como critério de constitucionalidade da contribuição a que se refere o artigo 149, caput, da Constituição Federal, assim como a regra que veda a tributação confiscatória, ou mesmo a eleição da livre concorrência como princípio da ordem econômica (Cf. FOLLONI, André. Ciência do direito tributário no Brasil, p. 399).

${ }^{19}$ Cf. SCHOUERI, Luís Eduardo. Tributação e indução econômica: os efeitos econômicos de um tributo como critério para sua constitucionalidade. In: FERRAZ, Roberto (coord.). Princípios e limites da tributação, vol 2 (Os Princípios da Ordem Econômica e a Tributação). São Paulo: Quartier Latin, 2009, pp. 139-164 (163164).
} 
De todo modo, deve-se deixar claro que uma postura metodologicamente dogmática que leve em consideração a complexidade do fenômeno tributário não se confunde, em absoluto, com uma análise econômica do direito ${ }^{20}$ - mesmo porque, é importante frisar, interdisciplinaridade pressupõe que haja disciplinas, apenas significando que o corte abstrato delas decorrente não inviabilize um conhecimento mais amplo do objeto de estudo ${ }^{21}$. Não há, assim, que se falar em sincretismo metodológico: não se apregoa a confusão entre os saberes científicos, mas sim a mera utilização instrumental de conceitos e premissas de outros ramos do conhecimento (particularmente da ciência das finanças) numa investigação precipuamente jurídica, que se funda em critérios próprios do direito.

Destaque-se: na análise jurídico-tributária que leva em conta a complexidade do objeto a ser estudado, embora se devam colher frutos de outros conhecimentos, tais critérios necessariamente deverão ser balizados num padrão próprio da ciência jurídica, buscando-se neles as consequências jurídicas impostas pelo ordenamento. "Complexo o objeto, complexo deve ser o estudo", adverte FOLLONI. O que não significa que se transforme o jurista num economista, cientista político, contabilista. Ao contrário: em linha com mencionado autor, “[m]uitas vezes, a boa compreensão, também do direito tributário, pode depender de visitação a outros campos do conhecimento científico"22.

Assentadas tais considerações a respeito do alcance da dogmática jurídica enquanto método, vale destacar que nela se distinguem três dimensões ${ }^{23}$, todas elas presentes, com maior ou menor intensidade, na presente pesquisa. A primeira delas, analítica, refere-se à "dissecação sistemático-conceitual do direito vigente" 24 e abrange desde o estudo de conceitos elementares às construções jurídicas a partir da relação entre tais conceitos, passando pelo exame de estruturas do sistema jurídico. Nesse contexto, assume relevância o método analítico-funcional ${ }^{25}$, porquanto voltado à compreensão da estrutura conceitual não só da progressividade enquanto técnica de tributação, mas também de seus fundamentos constitucionais, os quais, indutiva ou dedutivamente, permitirão construir a norma jurídico-constitucional em que se funda, servindo de baliza para a atuação

\footnotetext{
${ }^{20}$ A respeito da análise econômica do direito tributário, cf. CARVALHO, Cristiano. A análise econômica do direito tributário. In: SCHOUERI, Luís Eduardo (org.), Direito tributário: homenagem a Paulo de Barros Carvalho. São Paulo: Quartier Latin, 2008, pp. 183-206.

${ }^{21}$ Cf. FOLLONI, André. Ciência do direito tributário no Brasil: crítica e perspectivas a partir de José Souto Maior Borges. São Paulo: Saraiva, 2013, p. 336.

${ }^{22}$ Cf. FOLLONI, André. Ciência do direito tributário no Brasil, p. 400.

23 Cf., a respeito das três dimensões da dogmática jurídica, ALEXY, Robert. Teoria dos direitos fundamentais. Trad. Virgílio Afonso da Silva (orig. Theorie der Grundrechte, $5^{\mathrm{a}}$ ed.). São Paulo: Malheiros, 2008, pp. 33-36.

${ }^{24}$ Ibid., p. 33.

${ }^{25}$ Cf. ÁVILA, Humberto. Teoria da igualdade tributária, $3^{\mathrm{a}}$ ed. São Paulo: Malheiros, 2015, p. 33.
} 
do legislador infraconstitucional, seja no delineamento de desigualdades impositivas entre contribuintes, seja no estabelecimento de limitações que visem a proteger direitos fundamentais a eles assegurados.

No entanto, este estudo não se limita à compreensão dos elementos pertinentes e suas inter-relações, sendo fundamental também a dimensão empírica da dogmática jurídica, evidenciada no estudo da aplicação do direito a casos concretos, particularmente pelo Supremo Tribunal Federal, que porá em teste conceitos jurídicos no mais das vezes debatidos em plano exclusivamente teórico. A relevância dessa abordagem é demonstrada, por exemplo, na difícil compreensão, em plano abstrato, da noção de confisco, sendo certo que a definição de seu conteúdo e alcance depende, inexoravelmente, da análise da sua aplicação ao caso concreto. De fato, a despeito da temática específica da progressividade no imposto sobre a renda não ter sido objeto de grandes debates jurisprudenciais, outras questões ou tributos apreciados pelo Supremo Tribunal Federal permitirão avaliar a forma com a qual a jurisprudência constitucional relacionou os temas e conceitos aqui tratados, ainda que de uma forma mais genérica.

A esse respeito, ao contrário da mera exemplificação de ideias ou de argumentos de autoridade, o propósito é valer-se da jurisprudência numa espécie de mão dupla: ao mesmo tempo em que os precedentes do Supremo Tribunal Federal serão essenciais para o delineamento de alguns dos conceitos tratados, serão também objeto de um acompanhamento crítico, seja evidenciando eventual carência de coerência interna entre diferentes momentos da jurisprudência constitucional brasileira, seja expondo inconsistências ou acertos face ao pressuposto teórico da presente pesquisa ${ }^{26}$.

Por fim, aliada às dimensões analítica e empírica, também assume relevo a perspectiva normativa, enquanto precisa tradução do propósito de qualquer trabalho acadêmico: a propositura de soluções aos problemas enfrentados ${ }^{27}$. Em outras palavras, tratase do reconhecimento do destacado papel destinado à argumentação jurídica, isto é, o estudo e proposição de modelos teóricos que permitirão tanto testar a coerência dos fundamentos jurídicos que têm embasado a aplicação do direito positivo (no caso, constitucional), quanto determinar, a partir da norma posta, qual a mais coerente decisão a determinado caso concreto $^{28}$.

\footnotetext{
${ }^{26}$ Cf. SILVA, Virgílio Afonso da. Direitos fundamentais: conteúdo essencial, restrições e eficácia. $2^{\mathrm{a}}$ ed., $3^{\mathrm{a}}$ tiragem. São Paulo: Malheiros, 2014, p. 33.

${ }^{27}$ Cf. SILVA, Virgílio Afonso da. Direitos fundamentais, p. 32.

${ }^{28}$ Cf. ALEXY, Robert. Teoria dos direitos fundamentais. Trad. Virgílio Afonso da Silva (orig. Theorie der Grundrechte, $5^{\text {a }}$ ed.). São Paulo: Malheiros, 2008, p. 36.
} 


\section{Quais aspectos da progressividade no imposto sobre a renda?}

O tema tratado diz respeito tanto aos fundamentos, quanto ao controle da progressividade no imposto sobre a renda. Isso significa que o plano do estudo pode ser, logo num primeiro momento, dividido em duas partes: a primeira, de caráter mais geral, voltada à construção de seus fundamentos e da norma constitucional que a veicula; a segunda, mais específica, volta a atenção aos controles da atividade legislativa relativos à progressividade - tanto com relação às medidas adotadas pelo legislador ordinário que estejam em dissonância com esse objetivo quanto aos seus limites frente aos direitos fundamentais dos contribuintes.

Assim é que, no Capítulo 1, é avaliada a relação entre capacidade contributiva e progressividade, de modo a verificar quais concepções acerca da primeira podem, em maior ou menor grau, servir de fundamento para a segunda, bem como as dificuldades para tal abordagem. Diante de algum ceticismo quanto à possibilidade de a progressividade encontrar sua justificação na capacidade contributiva, especialmente com vistas às dificuldades das teorias do sacrifício, o Capítulo 2 buscará a construção de seus fundamentos constitucionais, especialmente considerando a sua prévia e expressa previsão na Constituição. Além disso e enquanto um desdobramento, é possível construir as normas acerca da progressividade no imposto sobre a renda que são veiculadas pela Constituição: a partir de uma perspectiva de alternativas inclusivas quanto às suas dimensões normativas, trata-se de reconhecer a existência tanto de uma regra quanto de um princípio, buscando distinguir seus conteúdo e eficácia.

Bem delimitados os fundamentos da progressividade no imposto sobre a renda e definidos os conteúdos e funções das normas constitucionais a ela relacionadas, cabe verificar, no Capítulo 3, até que ponto pode o legislador ordinário não ir no sentido desses objetivos. É que existe, no regramento infraconstitucional do imposto sobre a renda, uma série de elementos que acabam por mitigar os objetivos traduzidos na progressividade, o que, conforme o grau dessa restrição, pode demandar diferentes níveis de justificação - daí a relevância de identificar a intensidade com a qual mitigam a progressividade certas medidas como exceções na mensuração da sua base de cálculo, isenções ou deduções, assim como sistemáticas de tributação cedular, a exemplo de rendimentos provenientes de investimentos no mercado financeiro e de capitais, além dos ganhos de capital e das rendas empresariais. 
Não basta, contudo, que seja levada em consideração a previsão constitucional da progressividade, uma vez que também é assegurado, também pela própria Constituição, um extenso rol de direitos fundamentais aos contribuintes. É por essa razão que o Capítulo 4 tem por objeto os métodos que servirão para delimitar até que ponto pode o legislador ordinário ir na realização dos objetivos encerrados na progressividade no imposto sobre a renda. É bem verdade que esses métodos não devem ignorar a peculiar normatização constitucional da matéria, o que levará a questionar o sentido da aplicação do exame de proporcionalidade enquanto critério de controle. Ao mesmo tempo, destacam-se outros exames, especialmente a correspondência entre a medida determinada pela regra constitucional e a progressividade como delineada pela regra de incidência, bem como a razoabilidade e congruência da discriminação entre contribuintes. Por fim, assume relevância a vedação à utilização do imposto com efeitos de confisco, o que exige que se evidenciem as particularidades de sua aplicação no tocante à progressividade no imposto sobre a renda. 


\section{CONSIDERAÇÕES FINAIS}

Ao longo da presente pesquisa, três questões fundamentais foram colocadas. Por que a progressividade no imposto sobre a renda, do que se trata e no que se fundamenta? Quais aspectos do imposto sobre a renda mitigam essa progressividade e quais os critérios que devem ser adotados para controlar essas mitigações? E a quais limites e controles submete-se a progressividade no imposto sobre a renda face aos direitos fundamentais dos contribuintes, especialmente considerando sua específica disciplina constitucional? No percurso do caminho para respondê-las, foram alcançadas algumas conclusões parciais.

1. A justificação da norma tributária, cuja importância redunda na própria igualdade tributária, impõe que haja um fundamento para qualquer diferenciação (discriminação) entre contribuintes. Em matéria de impostos, essa justificação encontra-se, especialmente, na capacidade contributiva. A capacidade contributiva, prevista expressamente na Constituição, exerce diferentes funções no sistema tributário.

1.1. De um lado, revela-se como pressuposto da tributação, no sentido de que apenas podem ser objetos da incidência tributária manifestações de riqueza do contribuinte. Nesse sentido, são levadas em consideração as perspectivas tanto objetiva (ou seja, sinais que objetivamente exteriorizam manifestação de riqueza) quanto subjetiva (levando-se em conta aspectos pessoais do contribuinte).

1.2. Também a capacidade contributiva assume a função de parâmetro de graduação e distribuição do encargo tributário, no sentido de que aqueles que mais têm 
devam contribuir em maior montante ao custeio estatal. O problema da progressividade, portanto, tipicamente diz respeito a essa função da capacidade contributiva.

1.3. Por fim, relacionada à primeira função, a capacidade contributiva também revela o limite máximo de tributação, no sentido da manutenção da utilidade do direito de propriedade e da livre iniciativa da atividade econômica dos contribuintes

2. Se toda discriminação tributária deve ser justificada, surge a questão acerca do fundamento da progressividade no imposto sobre a renda. Num primeiro momento, cogitou-se sua justificação a partir da contrapartida aos benefícios provenientes da atuação estatal. Todavia, para fundamentá-la nesses termos, é preciso demonstrar que não apenas os benefícios provenientes do governo se incrementam quanto maior for a renda (o que já é, por si só, controverso), mas que esse incremento se dá desproporcionalmente ao próprio aumento da renda.

2.1. O grande problema dessa fundamentação da progressividade é ter como pressuposto que os benefícios não sejam meramente proporcionais à renda e à propriedade, ou seja, eles aumentam mais rapidamente conforme crescem tais índices de riqueza. É uma premissa baseada no Estado enquanto provedor de segurança, de modo que, tal como um seguro, quanto mais expressivo o capital segurado (ou protegido), maior o benefício decorrente dessa atuação.

2.2. Contudo, considerando serviços públicos, especialmente aqueles divisíveis, são tomados especialmente por aqueles que detêm menos recursos, a teoria do benefício poderia implicar, ao contrário, uma tributação regressiva. Assim é que a teoria do benefício não é adequada para justificar os impostos em geral, incondizentes com essa perspectiva sinalagmática, tampouco uma distribuição progressiva do seu encargo.

3. Especificamente quanto à capacidade contributiva, a progressividade é recorrentemente entendida como seu desdobramento, na medida em que implica que aqueles que mais têm paguem mais, além de refletir o caráter pessoal do imposto. Essa abordagem, contudo, deixa de lado o fato de que (i) também um imposto proporcional, com uma única alíquota, resultará esse ideal de equidade vertical e (ii) o caráter pessoal do imposto, relativo às peculiaridades do contribuinte, diz especial à mensuração de sua base de cálculo, se reflete essas especificidades.

3.1. As teorias do sacrifício partem da premissa de que a utilidade marginal da renda seria decrescente, isto é, o "valor" de cada unidade monetária, em termos de utilidade e satisfação, reduz-se quanto mais unidades monetárias auferir o contribuinte. Assim, se comprovadas suas premissas, a progressividade estaria justificada, uma vez que, com o 
decréscimo da utilidade marginal de cada unidade monetária, uma maior proporção de unidades monetárias deveria ser expropriada dos contribuintes mais abastados para que suportassem idêntico sacrifício sofrido pelos menos afortunados. Sob essas premissas, existem três perspectivas diferentes de enfrentar a questão da distribuição do encargo fiscal: o mínimo sacrifício, a igualdade absoluta de sacrifícios e a igualdade proporcional de sacrifícios.

3.1.1. A teoria do mínimo sacrifício baseia-se no princípio utilitarista de que a lei deve ser elaborada no sentido de prover a maior quantidade de satisfação para o maior número de indivíduos, ou seja, infligindo o mínimo sacrifício à sociedade como um todo. Sob essa perspectiva, se é verdadeiro o decréscimo de utilidade marginal do dinheiro, retirar unidades monetárias dos mais ricos lhes implica um sacrifício menor do que as retirar dos mais pobres, já que a correlação entre unidades monetárias e unidades de utilidade e satisfação, para os mais ricos, é menor - ou seja, uma unidade monetária é menos útil aos mais ricos que aos mais pobres. Essa abordagem, embora possa justificar o estabelecimento de uma faixa de isenção, pode implicar uma tributação francamente confiscatória, infligindo demasiada restrição (se não fulminação) da iniciativa privada, uma vez que acarretaria um igualitarismo desassociado de qualquer estímulo de mercado.

3.1.2. A teoria da igualdade absoluta de sacrifício diz respeito à equiparação de unidades de utilidade perdidas por cada contribuinte em razão da incidência do imposto, de modo que apenas embasará a existência de alíquotas progressivas a depender da efetiva curva de utilidade marginal aplicada ao caso, que deverá ser bastante acintosa. Isso porque, a depender dessa curva, pode suportar até mesmo uma tributação regressiva, como seria a um imposto per capita, que estaria absolutamente descolado da renda auferida e com as premissas da capacidade contributiva enquanto critério de graduação dos impostos. Nessa perspectiva, a teoria do sacrifício apenas sustentaria a progressividade se houvesse uma curva bastante acintosa de perda de utilidade marginal do dinheiro.

3.1.3. A igualdade proporcional de sacrifícios tem por pressuposto assegurar que todos os contribuintes sofram, por força da expropriação dos impostos, a mesma perda proporcional de bem-estar, o mesmo percentual de seu estoque de unidades de satisfação ou utilidade antes da tributação, independentemente do montante unidades monetárias dispendidas para o pagamento do imposto.

3.1.3.1. Para que possa justificar a progressividade, depende que se verifiquem três premissas: (i) que é possível correlacionar de forma substancial unidades monetárias e unidades de utilidade ou satisfação; (ii) que a curva de utilidade marginal da última unidade 
monetária é decrescente conforme aumenta o montante de unidades monetárias; e (iii) que essa curva é razoavelmente semelhante para todos os indivíduos.

3.1.3.2. Contudo, a teoria da igualdade proporcional de sacrifício não se mostra apta a demonstrar esse vínculo entre capacidade contributiva e progressividade, uma vez que: (i) não é possível comparar as utilidades e os sacrifícios com relação a diferentes contribuintes; (ii) não se pode afirmar que as curvas de utilidade sejam idênticas quanto a dois contribuintes diferentes; (iii) não se pode afirmar que seja tal curva, de fato, decrescente, dada a fungibilidade da utilidade proveniente da moeda; (iv) não é possível assegurar que um rendimento superior a outro propicie utilidade total superior à desse outro; (v) não se pode apurar a medida da diferença dessas utilidades; e (vi) a indeterminabilidade dessa curva de utilidade marginal inviabiliza o argumento, justamente porque a igualdade (proporcional) do sacrifício apenas levará à graduação progressiva de alíquotas marginais em determinados cenários bem específicos de perda de utilidade marginal; em outros, inclusive, poderia implicar uma tributação proporcional ou até mesmo regressiva.

3.2. Outro argumento que pretende atrelar a progressividade à capacidade contributiva globalmente considerada diz respeito à teoria da compensação, segundo a qual as alíquotas progressivas do imposto sobre a renda teriam a finalidade de compensar a regressividade própria dos outros tributos do sistema tributário. Embora tal premissa possa ser verdadeira, não é claro, no sistema brasileiro, que haja uma estrita coordenação normativa entre esses tributos, de forma tal que o desequilíbrio causado pela progressividade no padrão de distribuição do encargo conforme a capacidade contributiva seja contrabalanceado pela regressividade dos demais tributos e vice-versa. Tampouco essa compensação parece afastar a restrição que a progressividade, ao cabo, inflige ao direito a contribuinte em conformidade com a capacidade contributiva.

3.3. A capacidade contributiva, enquanto critério de graduação dos impostos, constitui um direito fundamental relacionado à distribuição do peso da carga tributária. Se as premissas das teorias do sacrifício não se confirmam, a progressividade no imposto sobre a renda imprime um desvio no padrão de distribuição do encargo do imposto conforme a capacidade contributiva. Em outras palavras, trata-se de restrição a esse direito fundamental, que deve, portanto, ser objeto de controle judicial.

4. Se apartada da capacidade contributiva, faz-se necessária a construção da justificação da progressividade no imposto de renda à luz da Constituição Federal, inclusive para fins de integração do conteúdo da respectiva norma constitucional. Em termos mais gerais, é possível vincular a progressividade à redução da concentração de renda, de uma 
forma tal que a curva de sua distribuição entre as unidades familiares se atenue após a incidência do imposto, equalizando-a, portanto. Essa constatação não é infirmada pela suposta ausência de capacidade redistributiva do imposto, em tese exclusiva do gasto público: a questão da alocação dos recursos a políticas públicas sociais, por meio de programas de transferência direta ou indireta aos grupos vulneráveis da sociedade, é intrinsecamente ligada à redução da pobreza, com o que não se confunde a atenuação da desigualdade de renda e de sua concentração. De todo modo, o potencial redistributivo da atuação estatal depende tanto das transferências de recursos quanto da progressividade da carga tributária - no que se insere, portanto, o imposto sobre a renda. Daí concluir-se que, se há um problema, uma ineficiência ou uma inconstitucionalidade com relação ao gasto público no Brasil, isso não significa que se deva abandonar a progressividade, mas que é necessária a correção do ponto problemático nessa correlação de tributo e gasto voltados à redistribuição de renda.

4.1. A Constituição Federal fundamenta textual e diretamente a progressividade no imposto sobre a renda (artigo $153, \S 2^{\circ}$, inciso I). Todavia, para a construção da norma constitucional da progressividade no imposto sobre a renda, não basta seu fundamento textual e direto, já que a Constituição, numa interpretação preambular, parece não determinar expressamente com relação a que, para que e com fundamento em que será progressivo. Para tanto, é necessário que se construa a norma a partir de fundamentos indiretos de que se podem deduzir e que induzem os seus elementos essenciais.

4.2. A partir de diversos dispositivos da Constituição Federal, é possível construir princípios de elevada estatura e função estruturante, como o princípio democrático ou o princípio do Estado Social, que normatizam determinados estados ideais de coisas a partir dos quais é possível deduzirem-se fundamentos de uma situação em que a carga tributária (ao menos dos impostos e, especialmente, do imposto sobre a renda) seja distribuída de forma desproporcional à distribuição de renda da população: não porque aqueles que auferem maior renda tenham capacidade contributiva em maior proporção, mas porque é tirando um maior quinhão de sua renda que se fomentará uma situação em que seja mitigada a concentração de riqueza e, por conseguinte, diminuídas as desigualdades sociais e econômicas - ou, ao menos, de renda.

4.2.1. Também finalidades ainda amplas, mas que decorrem do princípio do Estado Social e do princípio democrático, tais como a construção de uma sociedade livre, justa e solidária, além da erradicação da pobreza, da marginalização e redução das desigualdades sociais e regionais que permitem deduzir uma fundamentação constitucional 
para que a distribuição da carga tributária (ou dos impostos, ou, especialmente, do imposto sobre a renda) se dê de forma desproporcional na sociedade, contribuindo aqueles que mais têm com uma maior parcela de sua renda, no caso.

4.2.2. A esse propósito, pobreza e desigualdade não se confundem. Por essa razão, a erradicação da pobreza e da marginalização tem uma relação apenas mediata com a progressividade, já que depende, diretamente, de políticas de transferência de renda e seguridade social, ligadas ao gasto público. Ao contrário, a redução das desigualdades sociais e regionais traduz-se num fim bastante amplo da atuação estatal do qual se pode deduzir com bastante clareza a fundamentação para a tributação progressiva da renda. Também o objetivo de redução das desigualdades regionais pode fundamentar a progressividade, que a concentração de renda, no Brasil, também tem um matiz geográfico.

4.3. A Constituição Federal também prescreve diversos fins específicos (princípios) ou mesmo determinadas condutas impostas à Administração e asseguradas aos cidadãos (regra) que permitem induzir um estado ideal de coisas que também fundamenta uma distribuição proporcionalmente desigual da carga tributária (ao menos do imposto sobre a renda) na sociedade. São normas que tutelam os menos favorecidos em alguma dimensão e que têm, como fundamento, fins mais gerais que, por sua vez, também fundamentarão a progressividade no imposto sobre a renda. O caso mais evidente é o abrangente sistema de seguridade social estruturado pela Constituição Federal, mas também podem ser mencionados os direitos à educação, à alimentação, ao trabalho, à moradia, ao lazer, à segurança, à proteção à maternidade e à infância. Entendê-los como fundamentos indiretos por indução da progressividade no imposto sobre a renda não se baseia na suposição de que o produto de sua arrecadação tenha essa destinação. Ao contrário, são objetivos ou medidas que decorrem de fins mais amplos ligados à proteção dos mais vulneráveis, os quais igualmente servem de embasamento para a progressividade no imposto sobre a renda.

5. A partir dos fundamentos diretos e, especialmente, indiretos da progressividade no imposto sobre a renda é possível construir as normas constitucionais que a veiculam, seja a partir de uma dimensão que privilegie a prescrição de determinadas condutas ou comportamentos (regras), seja de certos fins ou estados ideais de coisas (princípios).

5.1. A Constituição, ao determinar que o imposto sobre a renda deveria ser “informado pelos critérios [...] da progressividade, na forma da lei” atribuiu a competência, ao legislador ordinário, de fixar alíquotas progressivas conforme a base de cálculo, num claro processo de ponderação entre, de um lado, os fundamentos da progressividade, 
notadamente relacionados à redução da desigualdade de renda e de sua concentração, e, de outro, demais direitos fundamentais que viessem a ser restringidos em razão da incidência progressiva do imposto. Daí dizer que a progressividade-regra é dotada de uma eficácia preliminarmente decisiva, já que é fruto de uma ponderação entre fins e valores conflitantes. Possui, além disso, uma função definitória, isto é, concretiza aqueles fins que the são subjacentes: são muitas as formas pelas quais se pode reduzir a desigualdade de renda e sua concentração; a progressividade, contudo, foi definida pelo legislador constituinte originário como uma dessas medidas que deverá ser adotada. Por essa razão, todas aquelas razões que levariam à sua adoção ou à sua recusa acabam bloqueadas pela regra, na medida em que não se fará mais necessária a ponderação entre elas.

5.2. De outro lado, também é possível compreender, a partir do texto constitucional, um estado ideal de coisas em que a distribuição da carga do imposto sobre a renda se dê de maneira desproporcional entre os contribuintes: aqueles que mais têm deverão arcar com uma maior proporção da sua renda ao custeio estatal. O que é interessante é verificar que, com relação a esse objetivo, não basta meramente a imposição de alíquotas progressivas, pois se faz necessária a adoção de uma série de outras medidas, relacionadas sobretudo à base de cálculo e à sistemática de tributação do imposto sobre a renda.

5.2.1. Trata-se, aqui, da função integrativa desse princípio, já que permite que se insiram determinados elementos na conformação infraconstitucional do imposto que, numa análise apressada, não se fariam presentes. Possui, ainda, a função de definir, ou concretizar, em matéria tributária, o conteúdo normativo de princípios constitucionais hierarquicamente superiores e semanticamente mais abrangentes.

5.2.2. A função bloqueadora exercida pela progressividade enquanto princípio implica o afastamento de elementos que, de forma expressa, sejam incompatíveis com esse estado ideal de coisas a ser fomentado. Acerca das exceções à sua aplicação, ao lado do bloqueio de imposição de medidas absolutamente regressivas, como seria o absurdo de um esquema de alíquotas que diminuíssem conforme aumentasse a renda auferida, também se verifica a eficácia argumentativa da progressividade enquanto princípio. Sob essa perspectiva, quanto maior for a restrição que a medida eleita pelo legislador ordinário impuser à consecução daquele objetivo, mais intensa deverá ser a justificação dessa medida, ou seja, mais fortes e normativamente mais relevantes deverão ser os fundamentos da exceção.

5.2.3. Assim, é acertado afirmar que o estado ideal de coisas versado pela progressividade enquanto princípio apenas pode ser fomentado se associado à universalidade 
e à generalidade, mediante um imposto com base de cálculo abrangente e poucas (senão nenhuma) exceções.

6. Por essa razão, apenas um conceito abrangente de renda se coaduna com a progressividade enquanto princípio, uma vez que é somente nessas condições que tal sistemática pode operar congruentemente com as finalidades que a justificam.

6.1. Nessa perspectiva, o modelo SHS não apresenta ganhos em termos de equidade apenas do ponto de vista horizontal, mas também assume papel crucial para que a progressividade do imposto se revele igualmente congruente com ditames derivados da perspectiva vertical da igualdade, pois permite incluir as diversas facetas do acréscimo de poder econômico do indivíduo, de modo a verificar se deverá ele contribuir ao custeio estatal em uma maior (se elevado o seu acréscimo) ou menor (se modesto o seu incremento) proporção de sua renda.

6.2. Do ponto de vista do sistema brasileiro, seja na definição de um conceito constitucional pressuposto, seja na conceituação propriamente dita, cabe à lei complementar - no caso, o Código Tributário Nacional - recortar e definir, dentro das amplas noções econômicas vistas e levando em conta as notas derivadas da Constituição, o conceito de renda para fins de imposição do imposto. Sob a perspectiva da progressividade enquanto princípio, o legislador complementar adotou decisões valorativas que houveram por corroborá-la, permitindo ao legislador ordinário a possibilidade de delinear um imposto sobre a renda condizente com os objetivos nela encerrados. Nem tão abrangente, a ponto de prejudicar a praticabilidade do imposto ou, no limite, de mitigar a capacidade contributiva na determinação do fato gerador, nem tão restritivo, chegando a inviabilizar uma mensuração da situação global do contribuinte que permita a consecução do objetivo de que aqueles que aufiram um montante mais elevado de renda contribuam com o custeio estatal numa proporção mais significativa dela.

6.3. Atrelada ao conceito de renda, portanto, está a mensuração da base de cálculo, que cumpre a função de, a um só tempo, (i) identificar os grupos de contribuintes que auferem um maior montante de renda; (ii) comparar grupos com diferentes níveis de renda; e (iii) viabilizar que o resultado final da obrigação tributária signifique que aqueles que aufiram maiores montantes de renda efetivamente contribuam ao custeio estatal, com o pagamento do imposto, um valor proporcionalmente mais expressivo se comparado a grupos com menores níveis de renda. Essa constatação é importante, pois evidencia que a progressividade não diz respeito apenas à alíquota aplicável, mas também à fixação da base de cálculo do imposto. 
6.3.1. A proteção do mínimo existencial, isto é, de recursos destinados às necessidades básicas e imprescindíveis à garantia da subsistência do contribuinte, decorre diretamente da própria capacidade contributiva, o que deve significar, aqui, que sequer de renda se trata essa parcela dos recursos financeiros do contribuinte.

6.3.1.1. Não compondo o montante da renda do contribuinte, fica demonstrado que não se confundem o imposto degressivo (aquele que combina uma faixa de isenção, tratada como "alíquota zero", e uma incidência proporcional a partir dali) e a progressividade.

6.3.1.2. Também essa premissa acerca da proteção do mínimo existencial tem implicações com relação à não correção do limite de isenção quanto aos efeitos da inflação: ano a ano, avança a tributação sobre parcela que fora considerada correspondente ao mínimo existencial. Há, nesse caso, a inconstitucionalidade decorrente da violação não apenas da regra de competência da União, mas também da própria igualdade tributária e da decorrente coerência que se exige nas decisões valorativas do legislador infraconstitucional, que acaba por contrariar, ano a ano, sua própria decisão legislativa de qual seria o patamar razoável do mínimo isento.

6.3.2. Ainda tratando da base de cálculo, há a questão das deduções, que toca fundo o problema do conceito de renda. Isso porque deve ser reconhecido que nem todo gasto representa consumo, assim como nem todo ingresso representa renda - daí a necessidade de apreciar, caso a caso, a natureza do dispêndio ou do rendimento, já que a noção de renda está diretamente atrelada ao acréscimo efetivo de poder econômico, isto é, de bens à disposição para o consumo.

6.3.2.1. Ocorre que, a partir do momento em que se questiona se determinadas deduções (ou a ausência de limites para elas) decorrem diretamente do conceito de renda e da capacidade contributiva enquanto pressuposto da tributação, assim como se podem encontrar neles seu fundamento, tais exclusões passam a mitigar os objetivos encerrados na progressividade enquanto princípio: na medida em que exoneram em maior monta aqueles que mais têm, importam significativa restrição a tal princípio, de tal sorte que a análise de sua constitucionalidade não pode passar ao largo dessa consideração.

6.3.2.2. Essa questão assume particular relevância quanto às deduções relacionadas à saúde e à educação. No primeiro caso, a ausência de limites pode fazer com que se deduzam dispêndios que vão muito além do que se possa entender como o mínimo existencial (logo, fora do conceito de renda) em matéria de saúde, como é o caso de hospitais de primeira linha, que também acabam por oferecer luxuosos serviços de hotelaria. 
Igualmente a educação, cujo limite para dedução tem sido reiteradamente questionado, pode traduzir dispêndios que vão além do que se admite excluir do conceito de renda. Ocorre que, se for assim, é cada vez mais restringido o objetivo de que aqueles que auferem mais renda contribuam ao custeio estatal com uma maior proporção dela. De fato, não apenas o imposto vê prejudicada sua aptidão para identificar aqueles que têm maior renda, já que a base imponível será diminuída com base em razões não ligadas ao conceito de renda e à capacidade contributiva, mas também não necessariamente aqueles que verifiquem o maior acréscimo patrimonial efetivamente contribuirão em maior proporção.

6.4. O problema da aplicação de isenções, exclusões ou deduções da base de cálculo que não guardem relação direta com o conceito de renda centra-se no fato de que a economia tributária (ou, por outra perspectiva, a subvenção indireta), por ser o produto entre a alíquota efetiva e o montante isentado, excluído ou deduzido, levará a um efeito regressivo, em que aquele que tiver maior renda será agraciado por uma subvenção indireta maior que aquele outro cuja renda é inferior, já que a alíquota efetiva a que se submete o primeiro é superior àquela aplicada ao segundo.

7. A sistemática de tributação também tem reflexos em matéria de progressividade. Assim é que a aplicação de um imposto cedular sobre determinados rendimentos, isolando-os das demais operações que comporão a base de cálculo do imposto sobre a renda, não apenas desconsidera o aspecto pessoal, como constitui óbice relevante à aplicação da progressividade. A constitucionalidade dessas exceções depende da relevância da justificação que lhes serve de fundamento e da proporcionalidade das restrições que impõe a outros princípios, como a universalidade e generalidade (corolários da própria capacidade contributiva) e também à progressividade.

7.1. O tratamento diferenciado de rendimentos auferidos no mercado financeiro é, no mais das vezes, justificado pela mobilidade do capital, de tal sorte que uma excessiva (ou mesmo alguma) tributação sobre o seu produto poderia afugentá-lo, além de desestimular a formação de poupança, entendida como essencial para o desenvolvimento econômico.

7.1.1. Essa segregação e incentivo, contudo, leva a significativas restrições à progressividade por três razões em especial. Em primeiro lugar, ao afastar-se de uma base de cálculo geral e universal, a tributação segregada dos rendimentos de aplicações financeiras mitiga a aptidão do imposto em capturar aqueles contribuintes com uma maior renda, para que contribuam com um percentual maior dela ao custeio estatal (como qualquer sistemática cedular, vale dizer). Em segundo lugar, os rendimentos derivados de investimentos (renda-poupada) se concentram, no geral, justamente entre aqueles que têm 
mais renda, de tal forma que a sua tributação segregada (e incentivada) implica que sejam eles beneficiados de forma especial se comparados com as camadas menos abastadas da sociedade, via de regra dependentes de rendimentos provenientes do trabalho. Em terceiro lugar, esses benefícios implicam uma subvenção indireta: quanto mais elevada for a renda de seu destinatário (e a alíquota efetiva aplicada), maior será em termos absolutos a economia fiscal dela decorrente.

7.1.2. A restrição à progressividade decorrente do atual regime diferenciado de tributação de rendimentos decorrentes de aplicação financeira é bastante intensa, exigindose fundamentação igualmente significativa para sua constitucionalidade. Essa análise, que deve levar em conta também o grau em que a medida é apta para fomentar os fins que a justificam, é relevante para evidenciar que, tratando da constitucionalidade de diferenciações realizadas pela legislação, algumas delas restringem em maior grau os objetivos da progressividade que outras, o que implica às primeiras um ônus mais significativo de justificação.

7.2. Tratando-se de ganhos de capital, vislumbram-se justificativas particulares para um tratamento diferenciado para fins de imposto sobre a renda. Embora uma alíquota elevada sobre ganhos de capital implique um efeito de detenção dos capitais (lock-in effect), esse argumento é comum à incidência de impostos em geral e eventuais ineficiências dela decorrentes, além do fato de que o imposto sempre será precificado. A principal particularidade dos ganhos de capital, contudo, diz respeito ao diferimento de sua tributação para o momento da realização e o resultante acúmulo de ganhos (bunching gains) que, na realidade, referem-se à mais-valia acumulada ao longo da manutenção da propriedade de certo capital por determinado contribuinte.

7.2.1. O principal aspecto desse acúmulo de mais-valias trata dos efeitos inflacionários, o que justifica que os ganhos de capital se submetam a uma alíquota inferior àquelas aplicáveis às rendas provenientes do trabalho. A aplicação de alíquotas progressivas de um imposto global (unitário) e pessoal a ganhos eventuais e extraordinários, como é o caso dos ganhos de capital, implicaria injustificadas restrições à igualdade vertical do imposto.

7.2.2. Recentemente, foi instituído um imposto progressivo sobre ganhos de capital no Brasil. Em primeiro lugar, pelas conclusões anteriores, é acertado que a alíquota máxima dessa nova graduação seja inferior à maior alíquota marginal da tabela progressiva regular. Em segundo lugar, embora se pudesse questionar a ausência de pessoalidade do imposto progressivo sobre ganhos de capitais, do ponto de vista prático, essa questão é 
relativizada pelo fato de que o corte estabelecido pela legislação é alto o suficiente para diminuir essas distorções decorrentes da não consideração da situação pessoal como um todo do contribuinte. Não será, portanto, a tendência que se verifiquem casos em que um indivíduo, embora tenha auferido mais ganhos que outro, será tributado em menor monta apenas porque os ganhos dividiram-se na alienação de vários bens diferentes.

7.3. Tratando-se de rendas empresariais (lucros e dividendos) e admitida a premissa da integração de que o imposto é pago pela sociedade à conta do sócio, o modelo brasileiro implica a sua tributação cedular, exclusivamente no nível das sociedades. Inclusive, a alíquota aplicável sobre os resultados decorrentes da atividade empresarial desenvolvida por intermédio de pessoas jurídicas (34\%, considerando a CSLL) é consideravelmente superior à alíquota marginal máxima do imposto das pessoas físicas $(27,5 \%)$. Há, contudo, dois aspectos do modelo de integração adotado no Brasil que implicam significativa restrição da progressividade.

7.3.1. Tratando-se de pessoas jurídicas sujeitas às sistemáticas do lucro presumido e arbitrado ou, ainda, de microempresas e de empresas de pequeno porte, a legislação, sob o fundamento da simplificação e praticabilidade, prevê a apuração estimada da base de cálculo do imposto sobre a renda a partir das receitas auferidas pela sociedade e, sobre essa estimativa, determina a aplicação das alíquotas dos tributos em referência. Ocorre que a legislação tributária prevê, expressamente, que, havendo escrituração contábil que evidencie lucro societário superior à base de cálculo do imposto descontada dos tributos pagos, poderão as sociedades distribuir a seus sócios o resultado apurado nas demonstrações financeiras sem qualquer tributação.

7.3.1.1. Embora não seja simples quantificá-la (o que já evidencia um grave problema de transparência), essa possibilidade prevista na legislação implica uma subvenção indireta àqueles que auferem rendas empresariais, o que traz consigo todas as implicações próprias desse tipo de benefício fiscal associado a uma tributação, em regra, progressiva, atribuindo-lhe de característica essencialmente regressiva.

7.3.1.2. Além disso, há a questão da dissociação entre rendimentos do trabalho de sócios (pró-labore) e rendas empresariais (lucros ou dividendos), para a qual a legislação brasileira atribuiu ampla discricionariedade à sociedade na determinação dos valores a que se refere um ou outro. O resultado disso é uma ampla margem para a elisão fiscal, maximizando a economia proveniente desse benefício fiscal e, por consequência, seus efeitos deletérios sobre a progressividade. 
7.3.2. A mera isenção das rendas empresariais faz com que contribuintes que aufiram demais rendimentos sejam tributados semelhantemente, ainda que um deles também aufira expressivo montante a título de lucros ou dividendos, implicando injustificada restrição à progressividade e à equidade vertical em geral. Daí ser correto afirmar que a aplicação da "reserva de progressão", instituto típico do direito tributário internacional e voltado à redução de possíveis iniquidades derivadas da isenção enquanto método para evitar a dupla tributação, poderia minimizar os efeitos perniciosos, sobre a progressividade, da integração entre pessoas jurídicas e físicas no sistema brasileiro vigente.

8. A imposição de alíquotas progressivas no imposto sobre a renda inflige restrições a direitos fundamentais dos contribuintes. Em primeiro lugar, ao direito fundamental a contribuir em conformidade com a capacidade contributiva, uma vez que há um desvio quanto à graduação baseada nela enquanto parâmetro. Em segundo lugar, ao direito de propriedade, tanto pelo fato de exigir daqueles que mais têm uma proporção incondizente com a graduação que se deriva da capacidade contributiva, seja na medida em que se utiliza o imposto sobre a renda como instrumento ("alavanca") para a consecução de determinados objetivos (“efeitos”) relacionados à redução da desigualdade de renda e de sua concentração. Em terceiro lugar, ainda que de forma mediata, também impõe uma restrição ao direito de liberdade dos contribuintes, na medida em que impacta o livre exercício da atividade econômica, a alocação de recursos no mercado e a tomada de decisões pelos agentes econômicos. Daí a constatação de que, havendo uma intervenção estatal sobre o âmbito de proteção desses direitos fundamentais, deverá ela ser submetida ao controle judicial, a fim de se averiguarem os limites a partir dos quais será reputada inconstitucional.

8.1. Tratando-se de restrição a direitos fundamentais, o primeiro método de controle que se destaca é o exame da proporcionalidade, que tem, como objeto, uma medida estatal específica (o que, em matéria tributária, será veiculado por lei na maior parte dos casos); como pressuposto, a existência de um princípio (fim) que guarde uma relação de causalidade (que justifique, portanto) essa medida; e a existência de outro(s) princípio(s) notadamente direitos fundamentais, mas não necessariamente - cuja realização seja, de algum modo, mitigada em razão da referida medida. Contudo, a par da dimensão normativa de regra que assume a progressividade na Constituição Federal, no particular caso brasileiro, é inadequado controlar as restrições a direitos fundamentais dela decorrentes por meio do exame de proporcionalidade, uma vez que seus juízos parciais (adequação, necessidade e proporcionalidade em sentido estrito) já foram predeterminados pelo legislador constituinte originário, de sorte tal que essa regra tem por função precípua o bloqueio das razões que 
poderiam ser consideradas não houvesse sido a situação normatizada por meio de, justamente, uma regra.

8.2. Se o pressuposto da inaplicabilidade do exame da proporcionalidade é o fato de a progressividade, enquanto medida, já haver sido predeterminada pelo legislador constituinte originário, é evidente que a regra infraconstitucional que impõe a incidência progressiva no imposto sobre a renda deve corresponder àquela progressividade prevista na Constituição. O exame de correspondência, nesse caso, não avalia a correlação entre o meio e o fim que o justifica, os graus de realização desse fim e de restrição a direitos fundamentais ou a fundamentação dessa restrição frente ao fomento desses objetivos. Daí por que a progressividade fixada pela regra infraconstitucional de incidência deve corresponder àquela predeterminada pelo legislador constituinte originário, cujo conceito é resultado também da função integrativa dos princípios constitucionais que lhe servem de fundamento.

8.3. Pode haver, contudo, razões extraordinárias que justifiquem a não aplicação da regra, baseadas no exame de razoabilidade. São situações específicas e concretas de contribuintes em particular, não se tratando da avaliação geral da causalidade entre meio e finalidade que lhe justifica, dos graus de fomento aos objetivos constitucionais e da restrição a direitos fundamentais ou da justificação da contribuição à realização desse fim face à limitação de direitos que inflige. Examina-se a congruência entre os elementos indicativos eleitos pelo legislador ordinário e a medida de comparação. Se é o elemento indicativo dessa medida que a concretiza, a ausência de congruência entre eles demonstra a inexistência de critério coerente de distinção, o que redunda numa discriminação arbitrária e, por conseguinte, passível de interdição judicial. Daí que, fosse aplicada a progressividade numa sistemática de tributação puramente cedular, por exemplo, haveria um descasamento entre, de um lado, a medida e o objetivo constitucional que a justifica e, de outro, a aplicação concreta do critério da norma, a qual seria irrazoável sob essa perspectiva.

8.4. Entre as garantias que a Constituição assegura aos contribuintes está a vedação ao emprego dos tributos com efeitos de confisco. Isso significa que há um mínimo de eficácia inviolável de direitos veiculados por regras constitucionais que delimitam e restringem a competência dos entes tributantes - como é o caso, especialmente, da capacidade contributiva enquanto limite máximo da tributação e da própria vedação à aniquilação da utilidade econômica do direito de propriedade e do livre exercício da atividade econômica.

8.4.1. "Efeito de confisco" não se confunde com "confisco". Assim, essa limitação ao poder de tributar não está adstrita às hipóteses em que toda a propriedade ou 
liberdade do contribuinte é extirpada, mas também àquelas em que essa restrição ou limitação é muito significativa, a ponto de inviabilizar ou inutilizar, do ponto de vista econômico, a fruição daquelas posições.

8.4.2. Para fins desse exame, é necessário que se apresentem fatos que permitam a demonstração dos interesses violados pela norma tributária, assim entendidos como as posições subjetivas do indivíduo a partir de determinados bens jurídicos. Em outras palavras, a demonstração da violação das condições mínimas para que o contribuinte usufrua utilmente sua propriedade e sua liberdade profissional.

8.4.3. Esse controle deve levar em consideração um conjunto de tributos cuja concorrência no agravamento da situação do contribuinte seja evidente. Não necessitará o julgador, a todo momento, levar em consideração a repercussão econômica dos tributos para verificar o grau de comprometimento que a carga tributária impôs ao contribuinte, pois haverá situações em que apenas a concorrência de alguns tributos, como aqueles que incidem sobre os vencimentos do contribuinte, já serão suficientes para demonstrar seus efeitos de confisco.

8.4.4. O exame atinente à vedação aos efeitos de confisco não se resume a um simples cotejo de alíquotas, mas diz respeito a todos os interesses juridicamente relevantes e constitucionalmente protegidos dos contribuintes. Por essa razão, apenas a alíquota efetiva, o ônus tributário real e a carga fiscal total podem permitir que se estimem os potenciais efeitos de confisco de que eventualmente se revistam os tributos.

8.5. O exame da complementariedade trata da necessidade de que as medidas tributárias sejam complementadas com as demais formas de atuação estatal nesse mesmo sentido. Tratando-se da progressividade no imposto sobre a renda, esse critério de controle pode resultar num resultado inverso à sua interdição: é justamente porque tanto o legislador constituinte originário quanto o legislador ordinário federal adotaram-na para a redução da desigualdade de renda e diminuição de sua concentração, que deve haver um reforço da obrigação do administrador público de adotar outras medidas que também contribuam com esse desiderato. A complementariedade, nesse sentido, exsurge como um argumento adicional no controle de políticas públicas e implementação de direitos sociais que se realiza nos tribunais brasileiros.

8.6. A análise da economicidade da norma tributária diz respeito ao controle de seus efeitos econômicos, sobretudo à luz dos princípios da Ordem Econômica, aproximandose sobremaneira do exame da tributação excessiva. Isso significa dizer que apenas se poderia cogitar a interdição judicial, sob esse critério, de medida tributária que se demonstrasse 
extremamente antieconômica. Do ponto de vista jurídico, há um elevado ônus argumentativo para levar adiante, enquanto critério de controle, a crítica econômica da progressividade no imposto sobre a renda, seja porque controversos os seus impactos econômicos, seja pela força da regra constitucional que a veicula, que reforça a necessidade da demonstração concreta desses efeitos econômicos alegadamente perniciosos.

As conclusões parciais alçadas ao longo desta pesquisa permitiram evidenciar a peculiaridade da normatização constitucional da progressividade no imposto sobre a renda, seja no sentido de demonstrar o ônus argumentativo que se impõe ao legislador ordinário quando da adoção de medidas que a mitiguem enquanto objetivo de que aqueles que mais têm contribuam com uma maior proporção de sua riqueza - ônus esse que é crescente à medida que se intensifica a restrição a esse fim -, seja demonstrando que a sua predeterminação constitucional não a torna insindicável perante o Poder Judiciário, sendo necessária a aplicação coerente de métodos de controles que busquem preservar os direitos fundamentais assegurados aos contribuintes pela Constituição. 


\section{REFERÊNCIAS BIBLIOGRÁFICAS}

ADAMY, Pedro. Instrumentalização do direito tributário. In: ÁVILA, Humberto (org.). Fundamentos do direito tributário. Madrid (Espanha): Marcial Pons, 2012, pp. 301329.

ALEXANDER, Larry. "With me, it's all er nuthin": formalism in law and morality. In: The University of Chicago Law Review, vol. 66, n. 3, 1999, pp. 530-565.

ALEXY, Robert. Teoria dos direitos fundamentais. Trad. Virgílio Afonso da Silva (orig. Theorie der Grundrechte, $5^{a}$ ed.). São Paulo: Malheiros, 2008.

ÁLVAREZ, José Antonio Martínez; BURGOS, Ana Belén Miquel; VILELA, Sofia Manjón. Simplicidad, neutralidad y equidad en los impuestos personales sobre la renta. El camino hacia la optimización impositiva. In: Cronica tributaria, n. 153, pp. 7-36, Madri (Espanha), 2014.

AMARANTE, Verónica; JIMÉNEZ, Juan Pablo. Desigualdad, concentración y rentas altas en América Latina. In: JIMÉNEZ, Juan Pablo (org.). Desigualdad, concentración del ingreso y tributación sobre las altas rentas en América Latina. Santiago (Chile): CEPAL, 2015. Disponível em <http://repositorio.cepal.org/ bitstream/handle/11362/37881/S1420855_es.pdf;jsessionid=406510F791D1C54A31B 7EFD8574D8397? sequence=1>. Acesso em 08.06.2017.

ANDREWS, Willian D. Personal deductions in an ideal income tax. In: Harvard Law Review, vol. 86, n. 2, dez./1972, pp. 309-385.

ANDREWS, Willian D. A consumption-type or cash Flow personal income tax, Harvard Law Review, vol. 87, n. 6, abr./1974, pp. 1.113-1.188.

ARZABE, Patrícia Helena Massa. $O$ direito à proteção contra a pobreza e a exclusão social. Tese (Doutorado). Universidade de São Paulo, 2001.

ATALIBA, Geraldo. IPTU - Progressividade. In: Revista de Direito Tributário, n. 56, ano 15, pp. 75-83, abril-junho/1991.

ÁVILA, Humberto. A distinção entre princípios e regras e a redefinição do dever de proporcionalidade. In: Revista de Direito Administrativo, n. 215. Rio de Janeiro, janeiro-março/1999, pp. 151-179.

Conteúdo, limites e intensidade dos controles de razoabilidade, de proporcionalidade e de excessividade das leis. In: Revista de Direito Administrativo, n. 236, Rio de Janeiro, abril-junho/2004, pp. 369-384.

Legalidade tributária multidimensional. In: FERRAZ, Roberto (coord.). Princípios e limites da tributação. São Paulo: Quartier Latin, 2005, pp. 277-291.

Limites à tributação com base na solidariedade social. In: GRECO, Marco Aurélio; GODOI, Marciano Seabra. (coords). Solidariedade social e tributação. São Paulo: Dialética, 2005, pp. 68-88. 
. Comportamento concorrencial e direito tributário. In: FERRAZ, Roberto (coord.). Princípios e Limites da Tributação, vol. 2 (Os Princípios da Ordem Econômica e a Tributação). São Paulo: Quartier Latin, 2009, pp. 427-440.

Malheiros, 2011.

Conceito de renda e compensação de prejuízos fiscais. São Paulo:

. Sistema constitucional tributário. 5a ed. São Paulo: Saraiva, 2012.

. Função da ciência do direito tributário: do formalismo epistemológico ao estruturalismo argumentativo. In: Revista Direito Tributário Atual, vol. 29, 2013, pp. 181-204.

Prefácio. In: FOLLONI, André. Ciência do direito tributário no Brasil: crítica e perspectivas a partir de José Souto Maior Borges. São Paulo: Saraiva, 2013, pp. 15-22.

- Ciência do direito tributário e discussão crítica. In: Revista Direito Tributário Atual, vol. 32. São Paulo, 2014, pp. 159-197.

. Teoria da igualdade tributária, $3^{\mathrm{a}}$ ed. São Paulo: Malheiros, 2015.

. Teoria dos princípios: da definição à aplicação dos princípios jurídicos.

$16^{\mathrm{a}}$ ed. São Paulo: Malheiros, 2015.

. Teoria da segurança jurídica. $4^{\mathrm{a}}$ ed. São Paulo: Malheiros, 2016.

AVI-YONAH, Reuven S. Why tax the rich? Efficiency, equity and progressive taxation. Review of Does Atlas shrug? The economic consequences of taxing the rich, by J. B. Slemrod, editor. Yale Law Journal, vol. 111, n. 6, pp. 1.391-1.416, 2002.

. Corporations, society, and the state: a defense of the corporate tax. In:

Virginia Law Review, vol. 90, n. 5, set./2004, pp. 1193-1255.

Tax competition, tax arbitrage and the international tax regime. In:

Bulletin for International Taxation, vol. 61, n. 4, 2007, pp. 130-138.

And yet it moves: a tax paradigm for the $21^{\text {st }}$ century. In: Law \& Economics Working Papers, n. 59. Disponível em <http://repository.law.umich.edu/law_econ_current/59>. Acesso em 01.10.2017.

AVI-YONAH, Reuven S.; SARTORI, Nicola; MARIAN, Omri. Global perspectives on income taxation law. Nova York (EUA): 2011.

BALEEIRO, Aliomar. Limitações constitucionais ao poder de tributar. Atual. Misabel Derzi. $8^{\mathrm{a}}$ ed. Rio de Janeiro: Forense, 2010.

BANKMAN, Joseph; GRIFFITH, Thomas. Social welfare and the rate structure: a new look at progressive taxation. In: California Law Review, vol. 75, n. 6, dez./1987, pp. 19051967. 
BARRETO, Aires Fernandino. Progressividade (conteúdo, sentido, limites de sua aplicação ao IPTU). In: TÔRRES, Heleno Taveira (coord.). Tratado de direito constitucional tributário: estudos em homenagem a Paulo de Barros Carvalho. São Paulo: Saraiva, 2005, pp. 441-464.

BARRETO, Paulo Ayres. Imposto sobre a renda e preços de transferência. São Paulo: Dialética, 2001.

. O imposto sobre a renda: pessoa física, pessoa jurídica e regime de fonte. In: BARRETO, Aires Fernandino; BOTALLO, Eduardo Domingos (coord.). Curso de iniciação em direito tributário. São Paulo: Dialética, 2004, pp. 109-130.

Planejamento tributário: limites normativos. São Paulo: Noeses, 2016.

BARRETO, Simone Rodrigues Costa. Mutação do conceito constitucional de mercadoria. Tese (Doutorado). Pontifícia Universidade Católica de São Paulo, 2014.

BIANCO, João Francisco. Inflação e imposto de renda da pessoa jurídica. Dissertação (Mestrado). Universidade de São Paulo, 1993.

BIRK, Richard M.; ZOLT, Eric M. Dual income taxation and developing countries. In: Columbia Journal of Tax Law, vol. 1, 2010, pp. 174-217.

BLUM, Walter J; KALVEN JR., Harry. The uneasy case for progressive taxation. University of Chicago Law Review, v. 19, n. 3, 1952, pp. 417-520.

BORBA, Eduardo José Paiva. A progressividade no Imposto de Renda Pessoa Física. In: ELALI, André; MACHADO SEGUNDO, Hugo de Brito; TRENNEPOHL, Terence (coord.). Direito tributário: homenagem a Hugo de Brito Machado. São Paulo: Quartier Latin, 2010, pp. 467-488.

BRAUNER. Yariv. Revisitando a (in)sensatez do imposto de renda das pessoas jurídicas. Trad. Gustavo Gonçalves Vettori e Natalie Matos Silva. In: Revista Direito Tributário Atual, vol. 21, 2007, pp. 61-102.

BRAZUNA, José Luís Ribeiro. A progressividade do IPTU. In: IOB-Repertório de Jurisprudência: tributário, constitucional e administrativo, n. 1, pp. 36-30, São Paulo, janeiro/2003.

BROWNLEE, W. Elliot. Historical perspective on U.S. tax policy toward the rich. In: SLEMROD, Joel B. Does Atlas shrug? The economic consequences of taxing the rich. Cambridge, Massachusetts (EUA): Harvard University Press, 2000, pp. 29-73.

BULHÕES PEDREIRA, José L. Imposto sobre a renda - pessoas jurídicas, vol. 1. Rio de Janeiro: Justec, 1979.

BURNS, Lee; KREVER, Richard. Individual income tax. In: THURONYI, Victor (org.). Tax law design and drafting, vol. 2. Washington (EUA): International Monetary Fund, 1998, pp. 495-563. 
CAGGIANO, Monica Herman S. A educação. Direito fundamental. In: RANIERI, Nina Beatriz Stocco (coord.). Direito à educação: Aspectos constitucionais. São Paulo: Editora da Universidade de São Paulo (EDUSP), 2009, pp. 19-37.

CANTO, Gilberto Ulhôa et al. Imposto sobre a renda e proventos de qualquer natureza. In: MARTINS, Ives Gandra da Silva (coord.). O fato gerador do imposto sobre a renda e proventos de qualquer natureza. São Paulo: Resenha Tributária, 1986, pp. 1-44.

CARRAZZA, Elizabeth Nazar. Progressividade e IPTU: igualdade e capacidade contributiva. $1^{\text {a }}$ ed., $3^{\text {a }}$ triagem. Curitiba: Juruá, 1999.

CARRAZZA, Roque Antonio. Imposto sobre a renda: perfil constitucional e temas específicos. $2^{a}$ ed. São Paulo: Malheiros, 2006.

A progressividade na ordem tributária. In: Revista de Direito Tributário, n. 64, pp. 43-55.

CARVALHO, Cristiano. A análise econômica do direito tributário. In: SCHOUERI, Luís Eduardo (org.), Direito tributário: homenagem a Paulo de Barros Carvalho. São Paulo: Quartier Latin, 2008, pp. 183-206.

CARVALHO, Paulo de Barros. Curso de direito tributário. $22^{\mathrm{a}}$ ed. São Paulo: Saraiva, 2010.

CASTRO, Fábio Avila; BUGARIN, Maurício Soares. A progressividade do imposto de renda da pessoa física no Brasil. In: Estudos Econômicos, vol. 47, n. 2, São Paulo, abr.jun./2017, pp. 259-293.

CAVALCANTI, Flavia. A integração da tributação das pessoas jurídicas e das pessoas físicas: uma análise calcada na neutralidade, equidade e eficiência. In: Revista Direito Tributário Atual, vol. 24, 2010, pp. 239-279.

CEPAL/IEF (Comisión Económica para América Latina y el Caribe/Instituto de Estudios Fiscales). Los efectos de la política fiscal sobre la redistribución en América Latina y la Unión Europea. Madri (Espanha): Cyan, Proyectos Editoriales, 2014. Disponível em <http://sia.eurosocial-ii.eu/files/docs/1412088027-Estudio_8_def_ final.pdf $>$. Acesso em 08.06.2017.

CHANCELLOR, Thomas. Imputed income and the ideal income tax. In: Oregon Law Review, vol. 67, 1988, pp. 561-610.

CONTI, José Maurício. Princípios tributários da capacidade contributiva e da progressividade. São Paulo: Dialética, 1996.

COSTA, Alcides Jorge. Imposto sobre a renda: a aquisição da disponibilidade jurídica ou econômica como seu fato gerador. Limite de sua incidência. In: Revista de Direito Tributário, vol. 40, abr.-jun./1987, pp. 103-107.

IPTU - progressividade. In: Revista de Direito Público, $n^{\circ}$ 93, janeiromarço/1990, pp. 239-242. 
. Capacidade contributiva. In: Revista de Direito Tributário, n. 55, ano 15, pp. 297-302, janeiro-março/1991.

. Conceito de renda tributável. In: MARTINS, Ives Gandra da Silva (coord.). Estudos sobre imposto de renda (em memória de Henry Tilbery). São Paulo: Resenha Tributária, 1994, pp. 19-31.

COSTA, Regina Helena. Princípio da capacidade contributiva. $2^{a}$ ed. São Paulo: Malheiros, 1996.

Imposto sobre a renda: generalidade, universalidade e progressividade. In: Revista de Direito Tributário, v. 94, p. 55-60, São Paulo, 2006.

COUTINHO, Diogo R. Direito, desigualdade e desenvolvimento. São Paulo: Saraiva, 2013.

DANIEL NETO, Carlos Augusto. O "mínimo existencial” como condição de derrotabilidade de regras tributárias. In: Direito tributário atual, vol. 37, 2017, pp. 84-106.

DERZI, Misabel Abreu Machado. Mutações, complexidade, tipo e conceito, sob o signo da segurança e da proteção da confiança. In: TÔRRES, Heleno Taveira (coord.). Tratado de direito constitucional tributário. Estudos em homenagem a Paulo de Barros Carvalho. São Paulo: Saraiva, 2005, pp. 245-284.

EINAUDI, Luigi. Mitos y paradojas de la justicia tributaria. Barcelona (Espanha): Ediciones Ariel, 1959.

FARO, Julio Pinheiro. Solidariedade e justiça fiscal: uma perspectiva diferente sobre a concretização de direitos a partir do dever de pagar impostos. In: Revista de Direito Constitucional e Internacional, v. 20, n. 81, out.-dez./2012, pp. 229-271.

FERREIRA FILHO, Manoel Gonçalves. Significação e alcance das 'cláusulas pétreas'. In: Revista de Direito Administrativo, n. 202, 1995, pp. 11-17.

Curso de direito constitucional, 36 edição. São Paulo: Saraiva, 2010.

FOLLONI, André. Ciência do direito tributário no Brasil: crítica e perspectivas a partir de José Souto Maior Borges. São Paulo: Saraiva, 2013.

FREEDMAN, Judith. Treatment of capital gains and losses. In: ESSERS, Peter e RIJKERS, Arie (orgs.). The notion of income from capital. Amsterdam (Holanda): IBFD, 2005, pp. 191-215.

FREITAS, Silvana de. Teto salarial será de R\$ 12.720, diz STF. Folha de São Paulo, São Paulo, 15.09.1999. Disponível em <http://www1.folha.uol.com.br/ fsp/brasil/fc1509199924.htm>. Acesso em 31.07.2017.

FRÍAS, Ángeles García. Balance de la jurisprudencia del Tribunal Constitucional Alemán sobre el impuesto sobre la renta. In: Revista Española de Derecho Financiero, vol. 122, abr.-jun./2004, pp. 243-269. 
GONÇALVES, José Artur Lima. Imposto sobre a renda: pressupostos constitucionais. $2^{\text {a }}$ tir. São Paulo: Malheiros, 2002.

GRAU, Eros. A ordem econômica na Constituição de 1988: interpretação e crítica. 16ª ed. São Paulo: Malheiros, 2014.

GRIZIOTTI, Benvenuto. Principios de ciencia de las finanzas. $6^{\mathrm{a}}$ ed. Trad. Dino Jarach. Buenos Aires (Argentina): Roque Depalma Editor, 1959.

GUASTINI, Riccardo. Interpretar y argumentar. Trad. Silvina Álvarez Medina. Madri (Espanha): Centro de Estudios Políticos y Constitucionales, 2014.

GUNN, Alan. The case for an income tax. In: The University of Chicago Law Review, vol. 46, 1979, pp. 370-400.

GUTIERREZ, Miguel Delgado. Da renda imputada. In: Direito Tributário Atual, vol. 23, 2009, pp. 356-365.

Imposto de renda: princípios da generalidade, da universalidade e da progressividade. São Paulo: Quartier Latin, 2014.

HABER NETO, Michel. A tributação e o financiamento do direito à saúde no Brasil. Dissertação (Mestrado). Universidade de São Paulo, 2012.

HABER NETO, Michel; FAVACHO, Fernando Gomes. A progressividade do IPTU, do IPVA e Contribuição ao SAT: o tributo como sanção de ato ilícito. In: Revista de Direito Tributário, n. 115, pp. 162-173, 2012.

HAIG, Robert Murray. The concept of income. In: HAIG, Robert Murray (coord.). The federal income tax. Columbia Income Tax Lectures. Nova York (EUA): Columbia University Press, 1921, pp. 1-28.

HALL, Robert E.; RABUSHKA, Alvin. The flat tax: the fairest, simplest, most efficient and workable plan yet proposed. Standford, Califórnia (EUA): Hoover Institution Press, 1985.

HAYEK, Friedrich. Reexaminando a tributação progressiva. Trad. Edson Bini. In: FERRAZ, Roberto (coord.). Princípios e limites da tributação. São Paulo: Quartier Latin, 2005, pp. 739-764.

HOLMES, Kevin. The concept of income: a multi-disciplinary analysis. Amsterdam (Holanda): IBFD, 2000.

INTERNATIONAL MONETARY FUND (IMF). Fiscal monitor: tackling inequality. Washington (EUA): International Monetary Fund, Publication Services, 2017.

JARACH, Dino. Finanzas públicas y derecho tributario. Buenos Aires (Argentina): Cangallo, 1993.

JOUMARD, Isabelle; PISU, Mauro; BLOCH, Debbie. Tackling income inequality: the role of taxes and transfers. In: OECD Journal: Economic Studies, 2012. Disponível em 
<https://www.oecd.org/eco/public-finance/TacklingincomeinequalityTheroleof taxesandtransfers.pdf > . Acesso em 06.06.2017.

KAVELAARS, Peter. Accrual versus realization. In: ESSERS, Peter e RIJKERS, Arie (orgs.). The notion of income from capital. Amsterdam (Holanda): IBFD, 2005, pp. 127-181.

KELMAN, Mark G. Personal deductions revisited: why they fit poorly in an 'ideal' Income Tax and why they fit worse in a far from ideal world, Stanford Law Review, vol. 31, n. 05, mai./1979, pp. 831-885.

KORNHAUSER, Marjorie E. The origins of capital gains taxations: what's law got to do with it. In: Southwestern Law Journal, vol. 39, 1985, pp. 869-928.

. The retoric of the anti-progressive income tax movement: a typical male reaction. Michigan Law Review, v. 86, pp. 465-523, dez./1987.

LANG, Joachim. The influence of tax principles on the taxation of income from capital. In: ESSERS, Peter; RIJKERS, Arie (orgs.). The notion of income from capital. Amsterdam (Holanda): IBFD, 2005, pp. 3-31.

LAPATZA, Jose Juan Ferreiro. Direito tributário: teoria geral do tributo. Barueri: Manole, 2007.

Justicia tributaria. In: Revista de Direito Tributário, v. 12, n. 46, pp. 7-16, São Paulo, out.-dez./1988.

LEÃO, Martha Toribio. A (des)proporcionalidade da progressividade do Imposto de Renda da Pessoa Física no sistema brasileiro. In: Revista Direito Tributário Atual, vol. 28, 2013, pp. 181-205.

Controle da extrafiscalidade. São Paulo: Quartier Latin, 2015.

O direito fundamental de economizar tributos: entre legalidade, liberdade e solidariedade. Tese (Doutorado). Universidade de São Paulo, 2017.

LEMGRUBER, Andréa. A tributação do capital: o Imposto de Renda da Pessoa Jurídica e o Imposto sobre Operações Financeiras. In: BIDERMAN, Ciro e ARVATE, Paulo (orgs.).

Economia do setor público no Brasil. Rio de Janeiro: Elsevier, 2004, pp. 206-230.

LEONETTI, Carlos Araújo. O imposto sobre a renda como instrumento de justiça social no Brasil. Barueri: Manole, 2003.

LIMA, Rafael Scavone Bellem de. Otimização de princípios, separação de Poderes e segurança jurídica: o conflito entre princípio e regra. Dissertação (Mestrado). Universidade de São Paulo, 2012.

LONGO, Carlos Alberto. Em defesa de um imposto de renda abrangente. São Paulo: FIPE-Pioneira, 1984. 
MACHADO, Brandão. Breve exame crítico do art. 43 do CTN. In: MARTINS, Ives Gandra da Silva (coord.). Estudos sobre o imposto de renda (em memória de Henry Tilbery). São Paulo: Resenha Tributária, 1994, pp. 107-124.

MACHADO, Hugo de Brito. A progressividade do IPTU e a capacidade contributiva. In: Revista Dialética de Direito Tributário, n. 203, pp. 91-100, São Paulo, 2002.

Curso de direito tributário. $31^{\text {a }}$ ed. São Paulo: Malheiros, 2010.

MACHADO, Raquel Cavalcanti Ramos. Competência tributária: entre a rigidez do sistema e a atualização interpretativa. São Paulo: Malheiros, 2014.

MADUEÑO, Denise. Salário de parlamentares sobe 59\% e de FHC, 49,6\%. Valores corresponderão a teto salarial para ministros do STF, de R $\$ 12.720$. Folha de São Paulo, São Paulo, 15.12.1998. Disponível em <http://www1.folha.uol.com.br/fsp/ brasil/fc15129802.htm>. Acesso em 31.07.2017.

MARTINS, Sérgio Pinto. Direito da seguridade social: custeio da seguridade social benefícios - acidente do trabalho - assistência social - saúde. $32^{a}$ ed. São Paulo: Atlas, 2012.

MCLURE JR., Charles E. Integration of the personal and corporate income taxes: the missing element in recent tax reform proposals. In: Harvard Law Review, vol. 88, $\mathrm{n}$. 3. Jan./1975, pp. 532-582.

MEDEIROS, Marcelo. Uma introdução às representações gráficas da desigualdade de renda. IPEA. Texto para discussão n. 1.202. 2006. Disponível em <http://www.ipea.gov.br/portal/images/stories/PDFs/TDs/td_1202.pdf>. Acesso em 06.06.2017.

MELLO, Gustavo Miguez. O imposto sobre a renda e proventos de qualquer natureza: alguns aspectos relevantes. In: $O$ fato gerador do imposto sobre a renda e proventos de qualquer natureza. Caderno de Pesquisas Tributárias $n^{\circ} 11$. São Paulo: Resenha Tributária, 1986, pp. 157-215.

MENDES, Gilmar Ferreira; BRANCO, Paulo Gustavo Gonet. Curso de direito constitucional. $7^{\mathrm{a}}$ ed. São Paulo: Saraiva, 2012.

MENKE, Cassiano. A proibição dos efeitos de confisco no direito tributário. São Paulo: Malheiros, 2008.

MILL, John Stuart. Principles of political economy with some of their applications to social philosophy. Londres (Reino Unido): Longmans Green and Co., 1920.

MIRANDA, Jorge. O preâmbulo da constituição. In: MIRANDA, Jorge (coord.). Estudos sobre a constituição. Vol. 1. Lisboa (Portugal): Petrony, 1977, pp. 17-25.

MOFFITT, Robert A.; WILHELM, Mark O. Taxation and the labor supply decisions of the affluent. In: SLEMROD, Joel B. Does Atlas shrug? The economic consequences of taxing the rich. Cambridge, Massachusetts (EUA): Harvard University Press, 2000, pp. 193-234. 
MOLINA, Pedro Manuel Herrera. Capacidad económica y sistema fiscal. Madrid: Marcial Pons, 1998.

MOREIRA, Clara Gomes. Controle de proporcionalidade das normas tributárias: compreensão e crítica à aplicação da proporcionalidade pelo Supremo Tribunal Federal. Dissertação (Mestrado). Universidade de São Paulo, 2016.

MORENO, Andrés Báez. Las tasas y los criterios de justicia en los ingresos públicos. Una depuración adicional del ámbito de aplicación del principio de la capacidad contributiva. In: Revista Española de Derecho Financiero, vol. 144, out.-dez./2009, pp. 953-969.

MOSQUERA, Roberto Quiroga. Renda e proventos de qualquer natureza: o imposto e o conceito constitucional. São Paulo: Dialética, 1996.

MURPHY, Liam. Why does inequality matter?: reflections on the political morality of Piketty's Capital in the Twenty-First Century. In: Tax Law Review, vol. 68, pp. 613629, 2014-2015.

MURPHY, Liam; NAGEL, Thomas. The myth of ownership: taxes and justice. Nova York (EUA): Oxford University Press, 2002.

MUSGRAVE, Richard A.; MUSGRAVE, Peggy B. Finanças públicas: teoria e prática. Trad. Carlos Alberto Primo Braga. São Paulo: Editora da Universidade de São Paulo: 1980.

MUTÉN, Leif. Treatment of capital gains and losses - a response. In: ESSERS, Peter e RIJKERS, Arie (orgs.). The notion of income from capital. Amsterdam (Holanda): IBFD, 2005, pp. 191-215.

NABAIS, José Casalta. Direito fiscal e tutela do ambiente em Portugal. In: TÔRRES, Heleno Taveira (org.). Direito tributário ambiental. São Paulo: Malheiros, 2005, pp. 412-444.

O dever fundamental de pagar impostos: contributo para a compreensão constitucional do estado fiscal contemporâneo. $4^{a}$ reimpressão. Coimbra (Portugal): Almedina, 2015.

NOGUEIRA, Ruy Barbosa. Curso de direito tributário. De acordo com a Constituição de 1988. $9^{a}$ ed. São Paulo: Saraiva, 1989.

NORONHA, Luana. Solidariedade social e tributação: uma análise constitucionalmente orientada. Revista Tributária e de Finanças Públicas, vol. 19, n. 96, pp. 71-100, São Paulo, janeiro - fevereiro / 2011.

ORGANISATION FOR ECONOMIC CO-OPERATION AND DEVELOPMENT (OECD), "Income inequality remains high in the face of weak recovery". 2016. Disponível em <http://www.oecd.org/social/OECD2016-Income-Inequality-Update.pdf>. Acesso em 07.06.2017.

OLIVEIRA, Regis Fernandes de. O IPTU progressivo. In: Revista de Direito Tributário, v.12, n. 43, pp. 165-166, São Paulo, jan.-mar./1988. 
OLIVEIRA, Ricardo Mariz de. Princípios fundamentais do imposto de renda. In: SCHOUERI, Luís Eduardo; ZILVETI, Fernando Aurélio (coords.). Direito tributário: estudos em homenagem a Brandão Machado. São Paulo: Dialética, 1998. pp. 197-227.

Fundamentos do imposto de renda. São Paulo: Quartier Latin, 2008.

ORIONE, Marcus Gonçalves Correia; CORREIA, Éria Paula Barcha. Curso de direito da seguridade social. $5^{a}$ ed. São Paulo: Saraiva, 2010.

ORTIZ, Diego González. Constitución, cargas familiares e imposición personal sobre la renta. In: Civitas: Revista Española de Derecho Financiero, n. 105, pp. 53-77, Madri (Espanha), janeiro-março/2000.

PIANCASTELLI, Marcelo, NASCIMENTO, Edson Ronaldo. Imposto de Renda da pessoa física. In: BIDERMAN, Ciro, ARVATE, Paulo (org.). Economia do setor público no Brasil. Rio de Janeiro: Elsevier, 2004, pp. 231-251.

PIKETTY, Thomas. O capital no século XXI. Trad. Monica Baumgarten de Bolle. Rio de Janeiro: Intrínseca, 2014.

POLIZELLI, Victor Borges. Progressividade: distribuição de renda e indução. In: Direito Tributário Atual, vol. 21, 2007, pp. 361-382.

O princípio da realização da renda: reconhecimento de receitas e despesas para fins do IRPJ. São Paulo: IBDT/Quartier Latin, 2012.

POLIZELLI, Victor Borges; GONZALES, Douglas Camarinha. Devem-se limitar as despesas com educação na Declaração de Imposto de Renda da Pessoa Física? In: Revista do Tribunal Regional Federal da 3 ${ }^{\text {a }}$ Região, v. 13, 2012, pp. 92-100.

QUEIROZ, Mary Elbe. Imposto sobre a renda e proventos de qualquer natureza. Barueri: Manole, 2004.

RECEITA FEDERAL DO BRASIL. Carga tributária no Brasil 2015: análise por tributos e bases de incidência. Disponível em <https://idg.receita.fazenda.gov.br/da dos/receitadata/estudos-e-tributarios-e-aduaneiros/estudos-e-estatisticas/carga-tribu taria-no-brasil/ctb-2015.pdf>. Acesso em 17.06.2017.

ROCHA, Paulo Victor Vieira da. Teoria dos direitos fundamentais em matéria tributária: restrições a direitos do contribuinte e proporcionalidade. São Paulo: Quartier Latin, 2017.

ROLAND, Débora da Silva. Possibilidade jurídica da progressividade tributária. São Paulo: MP Editora, 2006.

ROTHBARD, Murray B. The uneasy case for degressive taxation: a critique of Blum and Kalven. In: The Quarterly Journal of Austrian Economics, vol. 4, n. 1, pp. 43-61, 2001.

SANTOS JÚNIOR, Francisco Alves dos. O princípio da progressividade tributária na diminuição das diferenças, na terceira via e no consenso de Washington. In: Revista da Esmape, n. 13, vol. 6, pp. 153-204, Recife, janeiro - junho/2001. 
SANTOS, João Victor Guedes. Teoria da tributação e tributação da renda nos mercados financeiro e de capitais. São Paulo: Quartier Latin, 2013.

SANTOS, Ramon Tomazela. O princípio da universalidade na tributação da renda: análise acerca da possibilidade de atribuição de tratamento jurídico-tributário distinto a determinados tipos de rendimentos auferidos pelas pessoas físicas. In: Revista Direito Tributário Atual, v. 28, 2013, pp. 264-294.

SCAFF, Fernando Facury. Orçamento republicano e liberdade igual: direito financeiro, República e direitos fundamentais. Tese apresentada para concurso público de títulos e provas para provimento do Cargo de Professor Titular de Direito Financeiro da Faculdade de Direito da Universidade de São Paulo (Edital FD 22/2016). USP, 2017.

SCHAUER, Frederick. Formalism. In: The Yale Law Journal, vol. 97, n. 4, 1988, pp. 509548.

Playing by the rules: a philosophical examination of rule-based decision-making in Law and in life. Oxford (Reino Unido): Clarendon Law Series, 1991 (reimpressão 2002).

SCHOUERI, Luís Eduardo. Normas tributárias indutoras e intervenção econômica. Rio de Janeiro: Forense, 2005.

. Livre concorrência e tributação. In: ROCHA, Valdir de Oliveira (coord.). Grandes questões atuais do direito tributário, vol. 11. São Paulo: Dialética, 2007, pp. 241-271.

. Tributação e indução econômica: os efeitos econômicos de um tributo como critério para sua constitucionalidade. In: FERRAZ, Roberto (coord.). Princípios e Limites da Tributação, vol. 2 (Os Princípios da Ordem Econômica e a Tributação). São Paulo: Quartier Latin, 2009, pp. 139-164.

. O mito do lucro real na passagem da disponibilidade jurídica para a disponibilidade econômica. In: MOSQUERA, Roberto Quiroga; LOPES, Alexsandro Broedel (coord.). Controvérsias jurídico-contábeis (aproximações e distanciamentos). São Paulo: Dialética, 2010, pp. 241-264.

Juros sobre capital próprio: natureza jurídica e forma de apuração diante da "nova contabilidade". In: MOSQUERA, Roberto Quiroga; LOPES, Alexsandro Broedel (coord.). Controvérsias jurídico-contábeis (aproximações e distanciamentos), vol. 3. São Paulo: Dialética, 2012, pp. 169-193.

Prefácio. In: LEÃO, Martha Toribio. Controle da extrafiscalidade. São Paulo: Quartier Latin, 2015.

. Comentários a "Imposto sobre a renda: a aquisição da disponibilidade jurídica ou econômica como seu fato gerador". In: OLIVEIRA, Ricardo Mariz de; COSTA, Sérgio de Freitas (coords.). Diálogos póstumos com Alcides Jorge Costa. São Paulo: IBDT, 2017, pp. 236-239.

Direito tributário. $7^{a}$ ed. São Paulo: Saraiva: 2017. 
SCHOUERI, Luís Eduardo; TERSI, Vinícius Feliciano. A limitação à isenção dos dividendos pelo Parecer PGFN/CAT 202/2013. In: MOSQUERA, Roberto Quiroga; LOPES, Alexsandro Broedel (coord.). Controvérsias jurídico-contábeis (aproximações e distanciamentos), vol. 4. São Paulo: Dialética, 2013, pp. 104-121.

SELIGMAN, Edwin R. A. Progressive taxation in theory and practice. $2^{\mathrm{a}}$ ed. Princeton, Nova Jersey: Princeton University Press, 1909.

SEN, Amartya. Desigualdade reexaminada. Trad. Ricardo Doninelli Mendes. Rio de Janeiro: Record, 2001.

From income inequality to economic inequality. In: HENRY, C. Michael (coord.). Race, poverty and domestic policy. New Haven (EUA): Yale University Press, 2004, pp. 59-82.

SERNA, José Guillermo Baron. La progresividad en el sistema tributario colombiano. In: Revista del Colegio Mayor de Nuestra Señora del Rosario, v. 86, n. 562, Bogotá (Colômbia), dez./1993, pp. 3-28.

SHAVIRO, Daniel. The forgotten Henry Simons. In: Florida State University Law Review, vol. 41, n. 1, pp. 1-38, 2013.

SILVA, Emerson Drigo da. A progressividade no sistema constitucional brasileiro - algumas considerações a respeito. In: Revista Direito Tributário Atual, vol. 15, 1998, pp. 152173.

SILVA, José Afonso da. Curso de direito constitucional positivo. $29^{a}$ ed. São Paulo: Malheiros, 2007.

Aplicabilidade das normas constitucionais. $8^{\mathrm{a}}$ ed. $2^{\mathrm{a}}$ tiragem. São Paulo: Malheiros, 2012 (2015), p. 138.

Teoria do conhecimento constitucional. São Paulo: Malheiros, 2014.

SILVA, Natalie Matos. A integração da tributação das pessoas jurídicas e das pessoas físicas: análise dos modelos teóricos e de sua adequação ao princípio da capacidade contributiva. In: Revista Direito Tributário Atual, vol. 23, 2009, pp. 366-401.

SILVA, Virgílio Afonso da. Ulisses, as sereias e o poder constituinte derivado: sobre a inconstitucionalidade da dupla revisão e da alteração do quórum de 3/5 para aprovação de emendas constitucionais. In: Revista de Direito Administrativo, n. 226, 2001, pp. 11-32.

pp. 23-50.

O proporcional e o razoável. In: Revista dos Tribunais, vol. 78, 2002,

Direitos fundamentais: conteúdo essencial, restrições e eficácia. $2^{\mathrm{a}}$ ed., $3^{\text {a }}$ tiragem. São Paulo: Malheiros, 2014.

SILVEIRA, Rodrigo Maito, Tributação e concorrência. São Paulo: Quartier Latin, 2011.

SIMÕES, Aguinaldo. Princípios de segurança social. São Paulo: Saraiva, 1967. 
SIMONS, Henry C. Personal income taxation: the definition of income as a problem of fiscal policy. Chicago (EUA): The University of Chicago Press, 1938.

SINN, Hans-Werner. A Theory of the Welfare State. In: The Scandinavian Journal of Economics, v. 97, n. 4, "The Future of the Welfare State", dez./1995, pp. 495-526. Disponível em <http://www.jstor.org/stable/3440540>. Acesso em 07.06.2017.

SIQUEIRA, Rozane Bezerra de; NOGUEIRA, José Ricardo Bezerra; SOUZA, Evaldo Santana de. O sistema tributário brasileiro é regressivo?, fevereiro de 2012. Disponível em: <http://docplayer.com.br/24529152-O-sistema-tributario-brasileiro-eregressivo-rozane-bezerra-de-siqueira-jose-ricardo-bezerra-nogueira-evaldo-santa na-de-souza.html>. Acesso em 21.05.2017.

SLEMROD, Joel; BAKIJA, Jon. Taxing ourselves: a citizen's guide to the debate over taxes. $4^{\text {a }}$ ed. Cambridge, Massachusetts (EUA): The MIT Press, 2004.

SØRENSEN, Peter Birch. From the global income tax to the dual income tax: recent tax reforms in the Nordic countries. In: International Tax and Public Finance, vol. 1, 1994, pp. 57-79.

SOUSA, Rubens Gomes. Estudos de Direito Tributário. São Paulo: Saraiva, 1950. Financeiras, 1954.

Compêndio de legislação tributária. $2^{\mathrm{a}}$ ed. Rio de Janeiro: Edições . Imposto de Renda: Despesa não dedutíveis pelas pessoas jurídicas. Seu tratamento fiscal como "lucros distribuídos" no que se refere à própria sociedade e a seus sócios ou acionistas. In: SOUSA, Rubens Gomes de. Pareceres - 1 Imposto de Renda. Edição Póstuma. São Paulo: Resenha Tributária, 1975, pp. 59-95.

SURREY, Stanley S. Tax incentives as a device for implementing government policy: a comparison with direct government expenditures. In: Harvard Law Review, vol. 83, n. 4, fev./1970, pp. 705-738.

Federal income tax reform: the varied approaches necessary to replace tax expenditures with direct governmental assistance. In: Harvard Law Review, vol. 84, n. 2, dez./1970, pp. 352-408.

THURONYI, Victor. The concept of income. In: Tax Law Review, vol. 46, 1990, pp. $45-$ 106.

TILBERY, Henry. A tributação dos ganhos de capital. São Paulo: Resenha Tributária, 1977.

Imposto de renda: pessoas jurídicas - integração entre sociedade e sócios. São Paulo: Atlas, 1985.

O novo imposto de renda do Brasil: comentário à Lei $\mathrm{n}^{\circ} 7.713 / 88$ ajustado aos novos métodos de atualização monetária. São Paulo: IOB, 1989. 
TIPKE, Klaus. Princípio de igualdade e ideia de sistema no direito tributário. Trad. Luís Eduardo Schoueri. In: MACHADO, Brandão (coord.). Direito tributário: estudos em homenagem ao Prof. Ruy Barbosa Nogueira. São Paulo: Saraiva, 1984, pp. 515-527.

. Sobre a unidade da ordem jurídica tributária. Trad. Luís Eduardo Schoueri. In: SCHOUERI, Luís Eduardo; ZILVETI, Fernando Aurelio (coord.). Direito Tributário: estudos em homenagem a Brandão Machado. São Paulo: Dialética, 1998, pp. 60-70.

Fundamentos da justiça fiscal. In: TIPKE, Klaus; YAMASHITA, Douglas. Justiça fiscal e princípio da capacidade contributiva. São Paulo: Malheiros, 2002.

TIPKE, Klaus; LANG, Joachim. Direito tributário, vol. I. Trad. Luiz Dória Furquim (orig. Steuerrecht, 18 ${ }^{\mathrm{a}}$ edição). Porto Alegre: Sergio Antonio Fabris Editor, 2008.

TOMAZELA, Ramon. A progressividade do imposto de renda e os desafios de política fiscal. In: Revista de direito tributário atual, n. 33, pp. 327-358, 2015.

TORRES, Ricardo Lobo. O mínimo existencial e os direitos fundamentais. In: Revista de Direito Administrativo, vol. 177, jul.-set./1989, pp. 29-49.

Ética e justiça tributária. In: SCHOUERI, Luís Eduardo; ZILVETI, Fernando Aurelio (coord.). Direito tributário: estudos em homenagem a Brandão Machado. São Paulo: IBDT / Dialética, 1998, pp. 173-196.

. Tratado de direito constitucional financeiro e tributário, vol. III. Rio de Janeiro: Renovar, 2005.

. O direito ao mínimo existencial. Rio de Janeiro: Renovar, 2009, pp.

$184-185$

Justiça distributiva: social, política e fiscal. In: Revista de Direito Tributário, v. 70, pp. 27-39, São Paulo, s.d.

TURNIER, Willian J. Evaluating personal deductions in an income tax - the ideal. In: Cornell Law Review, vol. 66, n. 2, jan./1981, pp. 262-296.

UCKMAR, Victor. Princípios comuns de direito constitucional tributário. Trad. Marco Aurélio Greco. São Paulo: Revista dos Tribunais, 1976.

UNGER, Roberto Mangabeira. Democracy realized: the progressive alternative. Nova York (EUA): Verso, 1998.

VELLOSO, Andrei Pitten. O princípio da isonomia tributária: da teoria da igualdade ao controle das desigualdades impositivas. Porto Alegre: Livraria do Advogado, 2010.

VOGEL, Klaus. Tributos regulatórios e garantia da propriedade no direito constitucional da República Federal da Alemanha. In: MACHADO, Brandão (coord.). Direito tributário: estudos em homenagem ao Prof. Ruy Barbosa Nogueira. São Paulo: Saraiva, 1984, pp. 541-554. 
WUELLER, Paul H. Concepts of Taxable Income I - the German contribution. In: Political Science Quarterly, vol. 53, n. 1, mar./1938, pp. 83-110.

YAMASHITA, Douglas. Eficácia do princípio da capacidade contributiva no Brasil. In: TIPKE, Klaus; YAMASHITA, Douglas. Justiça fiscal e princípio da capacidade contributiva. São Paulo: Malheiros, 2002.

ZILVETI, Fernando Aurelio. Princípios de direito tributário e a capacidade contributiva. São Paulo: Quartier Latin. 2004.

Progressividade, justiça fiscal e capacidade contributiva. In: Revista Dialética de Direito Tributário, n. 76, pp. 27-32, janeiro/2002.

ZOCKUN, Maria Helena. Aumenta a regressividade dos impostos no Brasil. In: Informações FIPE, n. 297, junho de 2005. Disponível em: <http://downloads .fipe.org.br/content/downloads/publicacoes/bif/2005/6_bif297.pdf >. Acesso em 21.05.2017. 


\section{ACÓRDÃOS CITADOS}

\section{Supremo Tribunal Federal}

Recurso Extraordinário 18.033/SP, 2a Turma, Rel. Min. Orosimbo Nonato, j. 21.09.1951, DJ 08.11.1951.

Recurso Extraordinário 18.976/SP, $1^{\text {a }}$ Turma, Rel. Min. Barros Barreto, j. 02.10.1952, DJ 26.12.1952.

Recurso Extraordinário 117.887-6/SP, Plenário, Rel. Min. Carlos Velloso, j. 11.02.1993, DJ 23.04.1993.

Ação Direta de Inconstitucionalidade 939-7/DF, Plenário, Rel. Min. Sydney Sanches, j. 15.12.1993, DJ 18.03.1994.

Recurso Extraordinário 172.058-1/SC, Plenário, Rel. Min. Marco Aurélio, j. 30.06.1995, DJ 12.10.1995.

Ação Direta de Inconstitucionalidade 815/DF, Plenário, Rel. Min. Moreira Alves, j. 28.03.1996, DJ 10.05.1996.

Recurso Extraordinário 153.771/MG, Plenário, Rel. p/ acórdão Min. Moreira Alves, j. 20.11.1996, DJ 05.09.1997.

Recurso Extraordinário 234.105/SP, Plenário, Rel. Min. Carlos Velloso, j. 08.04.1999, DJ 31.03.2000.

Ação Direta de Inconstitucionalidade 1.946-5/DF, Plenário, Rel. Min. Sydney Sanches, j. 29.04.1999, DJ 14.09.2001.

Medida Cautelar na Ação Direta de Inconstitucionalidade 2.010/DF, Plenário, Rel. Min. Celso de Mello, j. 30.09.1999, DJ 12.04.2002.

Recurso Extraordinário 201.465-6/MG, Plenário, Rel. p/ acórdão Min. Nelson Jobim, j. 02.05.2002, DJ 17.10.2003.

Ação Direta de Inconstitucionalidade 2.076-5/AC. Plenário. Rel. Min. Carlos Velloso, j. em 15.08.2002, DJ 08.08.2003.

Ação Direta de Inconstitucionalidade 2.031/DF, Plenário, Rel. Min. Ellen Gracie, j. 03.10.2002, DJ 17.10.2003.

Recurso Extraordinário 413.782-8/SC, Plenário, Rel. Min. Marco Aurélio, j. 17.03.2005, DJ 03.06.2005.

Agravo Regimental no Recurso Extraordinário 463.210/SP, Segunda Turma, Rel. Min. Carlos Velloso, j. em 06.12.2005, DJ 03.02.2006. 
Medida Cautelar na Ação Direta de Inconstitucionalidade 1.075/DF, Plenário, Rel. Min. Celso de Mello, j. 17.06.1998, DJ 24.11.2006.

Agravo Regimental no Agravo de Instrumento 475.571/SP, Primeira Turma, Rel. Min. Marco Aurélio, j. em 26.04.2007.

Medida Cautelar na Ação Cautelar 1.657/RJ, Plenário, Rel. p/ acórdão Min. Cezar Peluso, j. 27.06.2007, DJ 31.08.2007.

Agravo Regimental na Ação Direta de Inconstitucionalidade 4.097/DF, Plenário, Rel. Min. Cezar Peluso, j. 08.10.2008, DJe 06.11.2008.

Agravo Regimental no Recurso Extraordinário 592.937/SC, Segunda Turma, Rel. Min. Cezar Peluso, j. em 12.05.2009.

Agravo Regimental no Recurso Extraordinário 448.432/CE, 2 a Turma, Rel. Min. Joaquim Barbosa, j. 20.04.2010, DJe 27.05.2010.

Medida Cautelar na Ação Direta de Inconstitucionalidade 1.945/MT, Plenário, Rel. p/ acórdão Min. Gilmar Mentes, j. 26.05.2010, DJe 11.03.2011.

Recurso Extraordinário 423.768/SP, Plenário, Rel. Min. Marco Aurélio, j. 01.12.2010, DJ 09.05.2011.

Recurso Extraordinário 562.045/RS, Plenário, Rel. p/ acórdão Cármen Lúcia, j. 06.02.2013, DJe 26.11.2013.

Ação Direta de Inconstitucionalidade 2.588/DF, Plenário, Rel. p/ acórdão Min. Joaquim Barbosa, j. 10.04.2013, DJe 11.02.2014.

Recurso Extraordinário 550.769/RJ, Plenário, Rel. Min. Joaquim Barbosa, j. 22.05.2013, DJe 02.04.2014.

Recurso Extraordinário 221.142/RS, Plenário, Rel. Min. Marco Aurélio, j. 20.11.2013, DJe 30.10.2014.

Agravo Interno no Recurso Extraordinário com Agravo 938.538/ES, $1^{\text {a }}$ Turma, Rel. Min. Roberto Barroso, j. 30.09.2016, DJe 20.10.2016.

\section{Tribunal Regional Federal da $3^{\text {a }}$ Região}

Arguição de Inconstitucionalidade Cível $\mathrm{n}^{\circ}$ 0005067-86.2002.4.03.6100/SP, Órgão Especial, Rel. Des. Federal Mairan Maia, j. 28.03.2012, DJe 14.05.2012. 